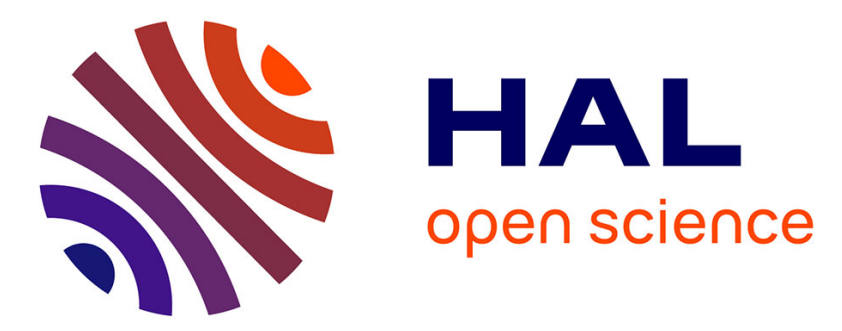

\title{
Supradetachment basin evolution unraveled by detrital apatite fission track analysis: the Gediz Graben (Menderes Massif, Western Turkey)
} Riccardo Asti, Marco Giovani Malusà, Claudio Faccenna

\section{- To cite this version:}

Riccardo Asti, Marco Giovani Malusà, Claudio Faccenna. Supradetachment basin evolution unraveled by detrital apatite fission track analysis: the Gediz Graben (Menderes Massif, Western Turkey). Basin Research, 2018, 30 (3), pp.502-521. 10.1111/bre.12262 . insu-01577210

\section{HAL Id: insu-01577210 https://hal-insu.archives-ouvertes.fr/insu-01577210}

Submitted on 25 Aug 2017

HAL is a multi-disciplinary open access archive for the deposit and dissemination of scientific research documents, whether they are published or not. The documents may come from teaching and research institutions in France or abroad, or from public or private research centers.
L'archive ouverte pluridisciplinaire HAL, est destinée au dépôt et à la diffusion de documents scientifiques de niveau recherche, publiés ou non, émanant des établissements d'enseignement et de recherche français ou étrangers, des laboratoires publics ou privés. 


\title{
Supradetachment basin evolution unraveled by detrital apatite fission track analysis: the Gediz Graben (Menderes Massif, Western Turkey)
}

Riccardo Asti ${ }^{1, *}$, Marco Giovanni Malusà ${ }^{2}$ and Claudio Faccenna ${ }^{3}$

${ }^{1}$ Université Rennes 1, Géosciences Rennes, UMR 6118, Rennes, France

${ }^{2}$ University of Milano-Bicocca, Department of Earth and Environmental Sciences, Milan, Italy

${ }^{3}$ Università degli Studi Roma Tre, Department of Sciences, Rome, Italy

*Corresponding Author:

Géosciences Rennes, UMR 6118, Université Rennes 1

Campus de Beaulieu, 35042 Rennes Cedex, France

Email : riccardo.asti@univ-rennes1.fr

Tel : +33223235495

\begin{abstract}
The Menderes Massif is a Tertiary metamorphic core complex tectonically exhumed in the late Oligocene - Miocene during coeval development of a series of E-W trending basins. This study analyzes the source-to-sink evolution of the Gediz Graben and the exhumation pattern of the Central Menderes Massif at the footwall and hanging wall of the Gediz Detachment Fault. We use a comprehensive approach to detrital apatite fission-track This article has been accepted for publication and undergone full peer review but has not been through the copyediting, typesetting, pagination and proofreading process, which may lead to differences between this version and the Version of Record. Please cite this article as doi: $10.1111 /$ bre. 12262

This article is protected by copyright. All rights reserved.
\end{abstract}


dating combining analysis of modern river sediments, analysis of fossil sedimentary successions, and mineral fertility determinations. This approach allowed us to: i) define the modern short-term erosion pattern of the study area, ii) unravel the long-term exhumation history, iii) identify major exhumation events recorded in the sedimentary basin fill and iv) constrain the maximum depositional age of the sedimentary succession. Three main exhumation events are recorded in the analyzed detrital samples: i) a late Oligocene/early Miocene exhumation event involving the whole Menderes Massif; ii) a late Miocene event involving the northern edge of the Central Menderes Massif; iii) a Plio-Quaternary more localized event involving only the western part of the southern margin of the basin (Salihli area) and bringing to the surface the Gediz Detachment and its intrusive footwall (Salihli granodiorite). The modern short-term erosion pattern closely reflects this latter PlioQuaternary event. Single grain-age distributions in the sedimentary basin fill highlight drainage pattern reorganizations in correspondence of the transition between different stratigraphic units, and allowed to better constrain the depositional age of the sedimentary units of the basin pointing to a possible onset of sedimentation in the basin during the middle Miocene.

Key words: detrital thermochronology; apatite fission track; supradetachment basin; Gediz Graben; Menderes Massif; Turkey

\section{Introduction}

The continental crust of the Aegean region experienced shortening and thickening followed by crustal extension starting from the Eocene (e.g. Jolivet \& Faccenna, 2000; Brun $\&$ Sokoutis, 2007). In regions of intense post-orogenic extension, upper-to-middle crustal rocks may be exhumed directly beneath unmetamorphosed upper crustal rocks, at the footwall of ductile-to-brittle detachment faults often associated with supradetachment basins (e.g. Van Hinsbergen \& Meulenkamp, 2006; Öner \& Dilek, 2011).

Supradetachment basins are common depositional settings associated to the exhumation of continental metamorphic core complexes (e.g. Gibbs, 1984; Lister \& Davis, 1989; Friedmann \& Burbank, 1995); these develop as the surface expression of buried extensional ductile-to-brittle shear zones and are characterized, in the late stages of their evolution, by the tectonic contact between the metamorphic footwall of the detachment and non- (or slightly) 
metamorphic sediments of the basin (e.g. Lister \& Davis, 1989). With their relatively high sedimentation rates $\left(10^{2}-10^{3} \mathrm{~m} / \mathrm{Ma}\right)$ (Friedmann \& Burbank, 1995, and references therein) their sedimentary fill may easily record major exhumation events involving the surrounding areas. Supradetachment basins can then provide useful pin-points for the paleotectonic reconstruction of these highly extended areas, but their full potential in recording relevant geological events is often unexploited.

In this work, we focus on the supradetachment basin of the Gediz Graben, in the Menderes Massif (SW Turkey), which will be used as a case history to illustrate the benefits of a comprehensive approach to detrital fission-track dating that combines analysis of modern river sediments, analysis of fossil sedimentary successions, and mineral fertility determinations. We use this approach to constrain the age of barren sedimentary successions inside the basin, to determine the modern erosion pattern, and to track the exhumation history of the footwall units. Our results allow us to propose a 4D reconstruction of the Gediz Graben evolution, which is eventually discussed within the framework of the Cenozoic evolution of the Menderes Massif.

\section{Geological setting}

\subsection{The Menderes Massif and the Gediz Detachment}

The Western Turkey sector of the Alpine-Himalayan belt has been site of major Cenozoic shortening followed by post-orogenic extension (Şengör et al., 1984; Şengör, 1987; Gessner et al., 2013). Shortening was produced by the collision of Africa-derived continental fragments, accreted along the southern margin of Laurasia and separated by major suture zones (Şengör \& Yilmaz, 1981; Şengör et al., 1984; Ring et al., 1999; Jolivet \& Brun, 2010).

The Menderes Massif (dark grey in Fig. 1) is ascribed to the southernmost of these continental fragments, namely the Tauride-Anatolide Platform (Şengör \& Yilmaz, 1981). It includes the deepest nappes of the Anatolide Belt (i.e., from top to bottom, the Selimiye, Çine, Bozdağ and Bayındır nappes; Ring et al., 1999, 2001; Gessner et al., 2013 and references therein), which preserve evidence of Panafrican, Variscan and Alpine tectonometamorphic events (Ring et al., 1999; Lips et al., 2001; Oberhänsli et al., 2010). These nappes, not distinguished in Fig. 1 for the sake of simplicity, were stacked in their present position during the Alpine orogeny. The uppermost Selimiye Nappe consists of low-grade 
metapelites, marbles and minor metabasites, with protolith ages ranging from Precambrian to Devonian-Carboniferous (Ring et al., 1999, 2001; Régnier et al., 2003). The Çine Nappe consists of orthogneisses and metagranites with protolith intrusion age of 530-560 Ma (Zlatkin et al., 2013), and minor pelitic gneisses, eclogites and amphibolites (Ring et al., 1999, 2001). The Bozdağ Nappe consists of metapelites with minor lenses of marbles, amphibolites and eclogites (Ring et al., 1999, 2001). The lowermost Bayındır Nappe consists of phyllites, quartzites and marbles with a greenschist facies metamorphic imprint of Alpine age (Ring et al., 1999, 2001; Lips et al., 2001).

The Menderes Massif is divided in three sub-massifs (i.e., Northern, Central and Southern Menderes) by the E-W trending Gediz Graben to the north and Büyük Menderes Graben to the south (Fig. 1). These grabens formed in Miocene times during the retreat of the Aegean subduction system and associated NNE-SSW extension of the Anatolide Belt (e.g. Şengör, 1987; Seyitoğlu \& Scott, 1996; Thomson \& Ring, 2006; Jolivet \& Brun, 2010). In the Gediz Graben area (Fig. 2), tectonic extension led to the formation of a gently dipping shear zone, the ductile-to-brittle Gediz Detachment, which separates greenschist-facies mylonitic gneiss in the footwall from unmetamorphosed Neogene sediments in the hanging wall (Hetzel et al., 1995; Işik et al., 2003). The Salihli and Turgutlu granodiorites were intruded during tectonic extension in early-middle Miocene times ( $15-17$ Ma; Glodny \& Hetzel, 2007: Rossetti et al., 2017), and are now exposed in the footwall of the Gediz Detachment. The Neogene-to-present deposits of the Gediz Graben lay tectonically on top of the detachment surface, and show SSW-ward tilted strata cut by high-angle normal faults that are rooted along the main detachment surface.

Thermochronologic data from previous work in the Menderes Massif highlight two major episodes of Cenozoic cooling (Gessner et al., 2001, 2013; Ring et al., 2003; Thomson \& Ring, 2006; Buscher et al., 2013). The earliest episode is referred to the late Oligocene early Miocene. The youngest episode only involved the Central Menderes Massif, and is constrained to the late Miocene - Quaternary by cooling ages that show a rejuvenation trend from $\mathrm{S}$ to $\mathrm{N}$ in the Gediz Graben area (Fig. 3a). By integrating different low-temperature thermochronometers (U-Th/He and fission tracks on apatite and zircon), Buscher et al. (2013) reconstructed the exhumation history of the Bozdağ region (at the southern margin of the Gediz Graben), highlighting an increase of the exhumation rate and of the slip rate on the Gediz Detachment between $~ 4$ and $~ 2 \mathrm{Ma}$.

This article is protected by copyright. All rights reserved. 


\subsection{The Gediz Detachment and the structure of the southern margin of the basin}

Major differences exist in the structure of the southern margin of the basin between the western (Salihli area) and the eastern (Alaşehir area) sector of the study area (Fig. 2).

In the Salihli area, the Gediz Detachment is largely exposed at the surface. It represents the most external structure of the basin and dominates the morphology of this part of the southern margin. In this area it consists of a ductile-to-brittle shear zone formed at the expenses of the Salihli granodiorite (Hetzel et al., 1995; Işik et al., 2003; Glodny \& Hetzel, 2007; Rossetti et al., 2017). The mylonitic foliation of the Gediz Detachment dips gently $\left(\sim 20^{\circ}\right)$ to the NNE and shows a penetrative $\sim$ N30 stretching lineation, with ductile and brittle kinematic indicators always pointing to a top-to-the-NNE sense of shear (Koçyiğit et al., 1999; Işik et al., 2003; Rossetti et al., 2017). On the western side of the Dereköy valley (which marks the limit between the Salihli and the Alaşehir areas) the dip of the detachment turns suddenly to the E together with the lineation on its surface (Seyitoğlu et al., 2015; Rossetti et al., 2017; Fig. 2).

In the Alaşehir area, the most external bounding structure of the basin is represented by patchy remnants of a gently NE-dipping fault surface $\left(\sim 20^{\circ}\right)$ (Bozkurt \& Sozbilir, 2004; Ciftci \& Bozkurt, 2008), characterized by slickenlines generally trending to the $\sim$ NE. At the footwall of this surface the metamorphic lithologies of the Çine nappe are exposed, with a metamorphic foliation generally dipping toward the $\sim$ SW (e.g. Sozbilir, 2001; Öner \& Dilek, 2011). Contrastingly with respect to the ductile deformation observed at the footwall of the Gediz Detachment in the Salihli area, here the kinematic indicators associated to the ductile deformation show ambiguous and inconsistent senses of shear, either pointing to a top-to-the$\mathrm{NE}$ and to a top-to-the-SW shearing. Another major difference between this fault surface and the Gediz Detachment surface exposed in the Salihli area is that this surface is dissected and displaced by younger high-angle normal faults (Bozkurt \& Sozbilir, 2004; Ciftci \& Bozkurt, 2008). These small remnants of a gently NE-dipping fault have been interpreted by previous studies as representing the lateral continuation in the Alaşehir area of the Gediz Detachment exposed in the Salihli area (e.g. Emre, 1996; Bozkurt \& Sozbilir, 2004; Ciftci \& Bozkurt, 2008; Öner \& Dilek, 2011; Seyitoğlu et al., 2015).

According to classic works, a continental detachment fault is defined as a gently-dipping normal fault characterized by a progressive and coherent ductile-to-brittle evolution. It is generally responsible for major footwall exhumation and put in contact crustal domains that,

This article is protected by copyright. All rights reserved. 
during a same period of time, experienced extension under extremely different pressuretemperature conditions (e.g. Lister \& Davis, 1989; John \& Cheadle, 2010; Whitney et al., 2013; Platt et al., 2015). Hanging wall rocks above the ductile-to-brittle detachment are commonly dissected by high-angle brittle normal faults rooting on the detachment that progressively rotate during extension to attend gentles dips (e.g. John \& Cheadle, 2010, and references therein). Thus, despite most of the previous studies that addressed the Gediz Graben have suggested that the Gediz Detachment extends to the E of the Dereköy valley and is thus exposed along the whole strike of the southern margin of the basin (e.g. Emre, 1996; Bozkurt \& Sozbilir, 2004; Ciftci \& Bozkurt, 2008; Öner \& Dilek, 2011; Seyitoğlu et al., 2015), our field observations and the re-interpretation of published data led us to interpret the southern margin of the basin exposed in the Alaşehir area (together with the above-mentioned gently dipping fault surface here exposed) as being in the hanging wall of the Gediz Detachment, which is instead exposed only more to the $\mathrm{W}$ in the Salihli area. In our opinion, the low-angle normal fault(s) exposed in the Alaşehir area does not display the characteristics to be strictly defined as a detachment fault, but rather those of a normal fault that has progressively rotated in the hanging wall of a buried detachment fault.

Evidence supporting this interpretation are: (i) the bending toward the $\mathrm{E}$ of the detachment surface (together with the associated lineation) in the western side of the Dereköy valley, and its dip below the eastern part of the southern margin; (ii) the lack of continuity between the detachment surface exposed in the Salihli area and the remnants of the low-angle brittle fault(s) exposed in the Alaşehir area; (iii) the lack of evidence in the Alaşehir area for a ductile deformation unambiguously related to a top-to-the-NE shearing, that is by contrast extremely evident in the Salihli area; (iv) the lack of clear evidence for a continuous extensional ductile-to-brittle evolution associated to the low-angle fault surfaces in the Alaşehir area, which is instead extremely evident on the Gediz Detachment shear zone in the Salihli area; (v) the general SW-dipping of the metamorphic foliation in the footwall of the low-angle brittle fault in the Alaşehir area, which is inconsistent with a top-to-the-NNE sense of shear on a gently NNE-dipping normal fault and with the metamorphic foliation observed in the Salihli area.

According to this interpretation, the Gediz Detachment has a domal shape enveloping the Salihli and the Turgutlu granodiorites, having its eastern termination in the western side of the Dereköy valley and its western termination likely around the Turgutlu area, to the W of the study area.

This article is protected by copyright. All rights reserved. 


\subsection{The Gediz Graben succession}

The evolution of the Gediz Graben is controlled by the activity of the Gediz Detachment and of the other normal faults bounding the northern margin of the Central Menderes Massif (Çiftçi \& Bozkurt, 2009; Öner \& Dilek, 2011). The onset of sedimentation and the age of the main sedimentary events are poorly constrained, but palynological data point to an earlymiddle Miocene age for the lowermost part of the basin fill (Seyitoğlu \& Scott, 1992; Ediger et al., 1996). Çiftçi \& Bozkurt (2009) suggested that the basin initially developed as a halfgraben, with a southern margin that was active during the Miocene, and changed its geometry in post-Miocene times with the activation of the northern margin.

The sedimentary evolution of the Gediz Graben has been the subject of a number of works (e.g., Iztan \& Yazman, 1991; Cohen et al., 1995; Emre, 1996; Koçyiğit et al., 1999; Sarica, 2000; Yilmaz et al., 2000; Seyitoğlu et al., 2002; Purvis \& Robertson, 2005; Çiftçi \& Bozkurt, 2009; Öner \& Dilek, 2011) proposing different stratigraphic subdivisions for the basin fill. Here, we use the nomenclature proposed by Çiftçi and Bozkurt (2009), with some modifications in order to take into account differences observed in the stratigraphic sequences between the western sector (Salihli area) and eastern sector (Alaşehir area) of the Gediz Graben. Four formations (Fm) can be distinguished on a lithostratigraphic ground on the southern margin of the basin (Fig. 2 and Fig. 3b). They are, from the bottom to the top: (i) the Alaşehir Fm, consisting of grey-to-brownish continental conglomerates and sandstones (Evrenli Member) heterotropic with lacustrine shales and siltstones (Zeytinçayi Member); (ii) the Çaltilik Fm, consisting of continental red sandstones and conglomerates with a few-tens of meters thick limestone interval in the lower part; (iii) the Gediz Fm, represented by yellowish continental sandstones and conglomerates with an overall coarsening-upward trend; and (iv) the unconformable Plio-Quaternary Kaletepe Fm, chiefly consisting of brownish continental conglomerates and sandstones with evidence of sediment recycling from the underlying formations. Quaternary fluvial deposits of the modern Gediz Graben are found on top of the Neogene-to-Quaternary sedimentary succession.

At the southern margin of the basin, major differences exist in the outcrop distribution of the different parts of the stratigraphic sequence between the Alasehir and the Salihli area (see Fig. 6). The oldest deposits of the sedimentary succession, i.e. Alaşehir Fm and lower part of the Çaltilik Fm, are exposed in outcrop only in the Alaşehir area (Yilmaz et al., 2000; Seyitoğlu et al., 2002; Purvis \& Robertson, 2005; Öner \& Dilek, 2011). This outcrop 
distribution of the lower part of the stratigraphic sequence has been differently interpreted by previous studies. Some authors suggested that this part of the stratigraphic sequence was deposited in an older NE-SW trending basin, later superimposed by the younger E-W trending Gediz Graben (e.g. Yilmaz et al., 2000). However, Çiftçi \& Bozkurt (2009) argued that this interpretation is unlikely and that the sedimentary features of the Alaşehir Fm point to deposition in the E-W trending Gediz Graben. Çiftçi \& Bozkurt (2010), based on seismic facies interpretation, suggested that the Alaşehir Fm never deposited in the Salihli area, and used this argument to infer an early E-W segmentation in three sub-basins with an east-towest trend of evolution. However, since no direct observation has yet documented the undeniable absence of the Alaşehir Fm buried below the sedimentary sequence in the Salihli area, its presence deep in the central part of the basin cannot be safely ruled out.

\section{Methodological approach}

This study is based on the analysis of fission tracks on detrital apatite grains (AFT hereafter). The AFT system, due to its closure temperature $\left(\sim 110 / 120^{\circ} \mathrm{C}\right.$; Gallagher et al., 1998), provides useful constraints on rock cooling and exhumation in the depth interval relevant for the evolution of detachment systems in the upper crust. Detrital AFT analysis can be used to:

a) Constrain the short-term erosion pattern of an area, provided that mineral fertility in bedrock is independently known (Resentini \& Malusà, 2012; Malusà et al., 2016);

b) Constrain the average long-term erosion rate within large areas by using few detrital samples, also taking into account the effects of drainage hypsometry (e.g., Brewer et al., 2003; Malusà \& Balestrieri, 2012);

c) Analyze the short-term erosion pattern in selected time intervals in the past (Malusà et $a l ., 2016)$, assuming a steady drainage network and same mineral fertility as today;

d) Identify major exhumation events recorded in ancient basin fills, and investigate the evolution of long-term exhumation by using the lag-time approach (Garver et al., 1999; Bernet et al., 2001), provided that isothermal surfaces are steady, the fissiontrack signal is not disturbed by post-depositional annealing, and that major change in provenance can be excluded.

e) Constrain the maximum depositional age of barren sedimentary successions, provided that post-depositional annealing is negligible (Carter, 1999).

This article is protected by copyright. All rights reserved. 


\subsection{Sampling strategy}

In order to fully exploit the potential of detrital AFT analysis, this study integrates the analysis of modern sediments and ancient sedimentary successions with independent mineral fertility determinations. We collected 13 samples of modern river sand within the Alaşehir/Gediz river drainage, and 9 samples from the Neogene-to-Quaternary basin fill (Table 1; Fig. 2 and Fig. 3). We sampled modern river tributaries (DX1 to DX3, and SX1 to SX 5) to measure apatite fertility in rocks exposed within the source area, and to define their AFT fingerprint. These samples were collected upstream of the Neogene-to-Quaternary basin fill, in order to avoid major bias due to sediment recycling. Samples SX3 to SX5 include detritus from the mylonitic shear zone of the Gediz Detachment and from the Bayındir nappe and Salihli granodiorite exposed in its footwall; samples SX1, SX2, and DX1 to DX3 include detritus from the Çine and Selimiye nappes exposed in the hanging wall. Five samples (M1 to M5) were collected along the Alaşehir/Gediz river trunk to detect the downstream change in the detrital AFT signal due to progressive input of different sources, and to perform sediment budgets calculations using the confluence sampling approach (Malusà et al., 2016). Samples of the Neogene-to-Quaternary basin fill (F1 to F9) have been collected to provide constraints on the depositional age of the basin fill and on the exhumation history and first exposure of the footwall units. Samples were collected along the southern margin of the basin (Fig. 3b), in order to minimize the potential impact of thermal resetting that might be expected in the central part of the graben. They encompass the whole stratigraphic sequence, and include: the Zeytinçayi Member of the Alaşehir Fm (F1 and F2), the Çaltilik Fm (F3 and F4 from the lower part, F5 and F6 from the upper part), the Gediz Fm (F7 and F8), and the Kaletepe Fm (F9).

\subsection{Laboratory procedures}

Apatite grains were concentrated in the laboratories of Milano-Bicocca University. For modern sand samples, we followed the procedure described in Malusà et al. (2016), which allowed us to maximize apatite recovery, measure apatite fertility in bedrock, and check samples for potential bias induced by hydraulic sorting. Samples were sieved at $1 \phi$ intervals to determine mean grain size and sorting, and we modeled the distribution of apatite grains in different grain-size classes by MinSORTING (Resentini et al., 2013), in order to choose the suitable grain-size classes for further mineral separation. We measured the grain density of the bulk sample using a hydrostatic balance, and performed a hydrodynamic pre- 
concentration of the dense fraction using a Gemeni shaking table. We processed different grain-size classes separately, in order to concentrate detrital grains according to their density and minimize the effect of grain size (Malusà et al., 2013). Dense fractions recovered after hydrodynamic pre-concentration were then merged together and purified in sodium polytungstate $\left(2.90 \mathrm{~kg} / \mathrm{dm}^{3}\right)$, and the dense mineral concentrate was weighed with a highprecision balance. The dense fraction was further refined using a Frantz magnetic separator and liquid diiodomethane $\left(3.32 \mathrm{~kg} / \mathrm{dm}^{3}\right)$. Quantities before and after each separation step were carefully weighed, and the percentage of apatite grains in the final concentrate was determined by point-counting under the microscope to get the final apatite concentration in the selected grain-size window. We added to this value the amount of apatite which is expected to be lost in the coarser and finer grain-size classes, as modeled by MinSORTING, and we used the dense mineral concentration and the bulk grain density values to check the sample for selective entrainment effects. If these values are close to reference values in eroded bedrock (cf. Malusà et al., 2016, their Fig. 6), apatite concentration measured in sediment is fully representative of apatite fertility in bedrock.

Samples from the Neogene-to-Quaternary basin fill were first processed with a jaw crusher and a disk mill in the laboratories of CNR-IGG in Pisa, and then sieved and processed like the modern sand samples, but without measuring dense mineral concentration and bulk grain density values. Mineral concentration in ancient sedimentary rocks is in fact strongly affected by differential mineral dissolution during diagenesis, which precludes a reliable estimate of mineral fertility in the source rock starting from sandstone samples (Malusà et al., 2016).

Apatite grains were prepared for irradiation according to the External Detector Method (Hurford, 1990), and were irradiated in the TRIGA-II reactor at Oregon State University. Fission tracks were counted at 1250x magnification using the FTstage-equipped Olympus microscope at Milano-Bicocca University. Apatite grains were fully characterized not only in terms of spontaneous and induced track densities, but also in terms of grain size, grain shape, and presence of crystal defects and fluid inclusions. We used the software Trackkey (Dunkl, 2002) to calculate grain ages, BinomFit (Brandon, 2002) to deconvolve the resulting single grain-age distributions into individual age components, and Radial Plotter (Vermeesch, 2009) to display grain ages and check samples for potential relationship between grain age, grain shape and grain size (Malusà et al., 2013; 2016). For polymodal samples, it is important to 
assess if minor age components are possibly missed whenever the number of analyzed grains is not large enough. For each sample, we thus determined the size of the smallest population fraction that was not missed with $95 \%$ of certitude, either under the hypothesis that grain-age populations are not uniformly distributed (Andersen, 2005) or under the more conservative hypothesis that all grain-age population have similar size (Vermeesch, 2004).

\section{Results}

Apatite fertility, dense mineral concentration and bulk grain density values yielded by tributary modern sand samples are summarized in Table 2. Results of AFT counting and the relative parameters used to calculate single grain-ages according to the zeta calibration method are reported in Table 3.

\subsection{Modern sand samples}

Apatite fertility values ranges from 120 to $734 \mathrm{mg} / \mathrm{kg}$ (Table 2 and supplementary Fig. 1SF). These values are higher in the hanging wall of the Gediz Detachment (average fertility $=550 \mathrm{mg} / \mathrm{kg}$ ) than in its footwall (average fertility $=185 \mathrm{mg} / \mathrm{kg}$ ) (Fig. 3b). Grain density values in these samples are in the range of $2.6 \pm 0.1 \mathrm{~kg} / \mathrm{dm}^{3}$ (supplementary Fig. 2SF), which excludes any major impact of selective entrainment on apatite concentration in modern sediment.

AFT ages yielded by modern sand samples are shown in the radial plots of Fig. 4. Most of these samples yielded polymodal grain-age distributions, with individual age components, summarized in Table 4, ranging from 2 to $110 \mathrm{Ma}$. In the light of the number of dated grains, we can be $95 \%$ certain that no population fraction smaller than 7-12\% was missed in polymodal samples from most of the tributaries, and that no fraction smaller than $3 \%$ was missed in samples M3 to M5 collected along the Alaşehir/Gediz river trunk (Andersen, 2005). No apparent relationship is observed between grain-age and grain-size, or between grain-age and grain-shape (supplementary Fig. 3SF), which attests that these grain age distributions are poorly vulnerable to hydraulic sorting effects.

Individual age components are younger in samples collected in the footwall of the Gediz Detachment than for those in its hanging wall (Fig. 4), consistent with available bedrock data (Fig. 3a). In samples collected on the southern margin of the basin (Fig. 5), the 
youngest age population gets progressively younger from the east ( $9 \mathrm{Ma})$ to the west $(\sim 2$ $\mathrm{Ma}$ ), where tributaries drain the detachment surface and the footwall units. In the main trunk river, the abundance of apatite grains with AFT age $<5 \mathrm{Ma}$, which are derived from the footwall of the Gediz Detachment, increase from 2\% in sample M3 to $14 \%$ in sample M4, and decrease again to $3 \%$ in sample M5. As expected, these young apatite grains are not found in samples M1 and M2, which are collected upstream of the Gediz Detachment.

\subsection{Samples of the Neogene-to-Quaternary succession}

AFT grain ages in samples from the Neogene-to-Quaternary sedimentary sequence are shown in the radial plots of Fig. 6. They either show unimodal or polymodal grain age distributions, with individual age components summarized in Fig. 7 and in Table 4. In the light of the number of dated grains, we can be $95 \%$ certain that no population fraction smaller than $3 \%$ was missed in polymodal samples (Andersen, 2005). Major peaks recognized in each formation get younger upsection (e.g., from $29.4 \pm 2.5$ to $16 \pm 1.4 \mathrm{Ma}$ in the Alaşehir Fm), as expected in the case of progressive unroofing of the source area. This trend also allows us to exclude any major perturbation of the AFT signal due to burial and postdepositional annealing in the lowermost strata of the basin fill. Post-depositional annealing, in fact, would produce an opposite age trend with decreasing AFT ages with depth (Malusà et al., 2011, their Fig. 3). Therefore, the AFT age peak in the Alaşehir Fm, as well as the youngest age populations of the overlying formations, can be safely used to constrain the maximum depositional age. In these samples, major provenance changes between different formations are marked by the addition of older sets of peaks also decreasing in age moving upsection. For instance, a major age peak at 32.1+6.9/-5.7 Ma first appears in the lowermost sample of the Çaltilik Fm, and gets progressively younger upsection reaching 17.5 +5.9/-3.9 Ma in sample F5 (Fig. 7).

A late Miocene age peak first appears in the upper part of the Çaltilik Fm (sample F5) $(6.3+2.6 /-1.8 \mathrm{Ma})$ and also characterizes the whole Gediz Fm. Older age peaks additionally found in samples F9 (i.e. $21.1+5.5 /-4.3 \mathrm{Ma}$ and $36.2+19.8 /-12.8 \mathrm{Ma}$ ) point to a new provenance change, and to a larger source area for the Kaletepe Fm compared to the underlying Gediz Fm (Fig. 7).

This article is protected by copyright. All rights reserved. 


\section{Discussion}

\subsection{AFT age pattern derived from detrital data}

Available bedrock AFT data in the Menders Massif published in previous works (e.g. Gessner et al., 2001, 2013; Ring et al., 2003; Thomson \& Ring, 2006; Buscher et al., 2013) were collected along transects, thus leaving wide areas of the massif devoid of low temperature thermochronologic constraints. Our detrital AFT dataset provides additional thermochronologic constraints to the exhumation history of the massif over a wider area. Samples collected in the main river's tributaries (SX1 to SX5 and DX1 to DX3) include detritus derived from relatively small and lithologically uniform areas, where mineral fertility variations are expected to be minor. They yielded single grain-age distributions not dependent on grain size and grain shape, and thus poorly vulnerable to hydrodynamic processes. As a consequence, these detrital AFT age distributions are expected to faithfully reflect the cooling-age pattern of the source area as mediated by the hypsometry of the drainage.

Tributary samples from the northern margin of the graben show not only grain-age populations consistent with available bedrock data within the basin (e.g., the youngest peaks in samples DX1 and DX2), but also grain-age populations much older than expected (e.g., sample DX3 and older peaks in samples DX1 and DX2). These older populations may suggest that bedrock units exposed within the drainage were not completely reset, at least in places, during nappe-stacking in the Cenozoic. Such older grain-age populations are also observed in tributaries draining the southern margin of the graben, particularly in those subbasins draining the hanging wall of the Gediz Detachment (samples SX1 and SX2) and the klippen atop the detachment surface (sample SX5 and probably sample SX3) (see Fig. 2).

Samples from the southern margin of the graben additionally highlight progressive cooling-age variations along strike (Fig. 5). Samples SX3 to SX5, from catchments draining the Gediz Detachment and its footwall, yielded very young AFT cooling-ages (Pliocene or younger) attesting to fast Plio-Quaternary exhumation as also indicated by available bedrock AFT data within the drainage (e.g., Gessner et al., 2001; Buscher et al., 2013). The youngest AFT age populations get progressively older moving towards the hanging wall of the Gediz Detachment, which consists of metamorphic rocks of the Çine nappe, reaching 9.3 $\pm 2.8 \mathrm{Ma}$ in sample SX1. This suggests that the western portion of the southern margin (Salihli area), 
including the Salihli granodiorite and the mylonitic-to-ultracataclastic Gediz Detachment, have experienced a deeper Plio-Quaternary exhumation than the Alaşehir area and that bedrock AFT ages measured on the Salihli granodiorite cannot be safely extrapolated along strike to the whole southern margin of the Gediz Graben. This younger and localized exhumation event may correspond to the increase of the exhumation rate and of the slip rate on the Gediz Detachment between ca. 4 and 2 Ma suggested by Buscher et al. (2013). The tectonic causes for the localization of this latter exhumation event might be related to linkage of the active fault segments bounding the southern margin of the modern Gediz Graben alluvial plain; as a matter of fact, Kent et al. (2016) suggested that the present day topography of the southern margin of the basin is the result of interaction and linkage between these fault segments, occurring between 2.6 and $2 \mathrm{Ma}$, that produced an enhanced uplift in the Salihli area in the Quaternary. The exhumation pattern at the southern margin of the Gediz Graben supports the hypothesis, based on field observations, that the eastern part of the southern margin is at the hanging wall of the Gediz Detachment and thus the detachment surface is not exposed along the whole strike of the basin margin.

By considering the geothermal gradient of $\sim 70^{\circ} \mathrm{C} / \mathrm{km}$ obtained after temperature measurements in wells in the Alaşehir area (Karamanderesi, 2013), the footwall of the detachment (cooling age from sample SX4; cooling rate $=58.6 \pm 14.6^{\circ} \mathrm{C} / \mathrm{Ma}$ ) shows an average exhumation rate of $0.84 \pm 0.21 \mathrm{~km} / \mathrm{Ma}$ (mediated over the last $\sim 2 \mathrm{Ma}$ ), while its hanging wall (cooling age from the youngest age peak of sample SX1; cooling rate $=18.7 \pm$ $4.2^{\circ} \mathrm{C} / \mathrm{Ma}$ ) shows an average exhumation rate of $0.17 \pm 0.05 \mathrm{~km} / \mathrm{Ma}$ (mediated over the last $\sim 9 \mathrm{Ma}$ ); at the transition zone between these two domains at the southern margin of the basin (cooling age from the youngest age peak of sample SX2; cooling rate $=12.3 \pm 3.6^{\circ} \mathrm{C} / \mathrm{Ma}$ ) the average exhumation rate is $0.27 \pm 0.06 \mathrm{~km} / \mathrm{Ma}$ (mediated over the last $\sim 6 \mathrm{Ma}$ ).

The two latter exhumation events (late Miocene and Plio-Quaternary) likely involved only the northern margin of the Central Menderes Massif, thus suggesting that the structures that controlled the Gediz Graben and the Büyük Menderes Graben to the $\mathrm{S}$ were not responsible for the exhumation of the whole Central Menderes Massif, but only for localized exhumation at its northern and southern margins (see also Gessner et al., 2001; Ring et al., 2003). As a matter of fact, some early Miocene bedrock AFT ages predating the formation of the Gediz Graben and the activation of the structures controlling its evolution are preserved in the central part of the Central Menderes Massif (Gessner et al., 2001; Ring et al., 2003). In 
the light of these considerations, we consider unlikely any model claiming for a complete exhumation of the Central Menderes Massif as a whole since the late Miocene.

\subsection{Short-term erosion pattern based on modern sediments}

Units exposed in the footwall of the Gediz Detachment have, on average, lower apatite fertility than units exposed in the hanging wall $(185 \mathrm{mg} / \mathrm{kg}$ vs $550 \mathrm{mg} / \mathrm{kg})$. Therefore, when detritus from both the hanging wall and the footwall units is admixed in the main river, the young ( $<5 \mathrm{Ma}$ ) AFT ages specific of the footwall units are expected to be underrepresented by a factor of 0.33 in the detrital AFT record. This is crucial when grain age distributions are used to perform sediment budgets starting from single-grain analyses, to constrain the erosion pattern on short-term timescales using the confluence sampling approach (Malusà et al., 2016). In this perspective, we compared the single grain-age distribution in modern sediment samples M3, M4 and M5, all including apatite grains derived from the footwall of the Gediz Detachment (AFT age <5 Ma), with those of upstream tributaries (SX1 to SX5 and DX1 to DX3), taking into account both the size of sub-basins contributing specific grain-age populations, and the average apatite fertility in each sub-basin.

For sample M4, we found that the erosion rate in the detachment area and in its footwall is $\sim 3.5$ times higher than the erosion rate in the rest of the drainage. For sample M5, which also includes detritus from the Northern Menderes Massif, the AFT age distribution suggests instead that this latter area might be eroded at rates that are only $15 \%$ slower than those characterizing the footwall of the Gediz Detachment. This is in line with the observation that the Northern Menderes Massif area also includes Neogene continental basins, which are expected to be eroded at much faster rates than the underlying metamorphic rocks. These relative erosion rates can be converted into absolute values by using the ${ }^{10} \mathrm{Be}-$ derived mean erosion rate of $110 \pm 10 \mathrm{~mm} / \mathrm{ka}$ calculated for the Gediz Detachment area by Buscher et al. (2013). By integrating this cosmogenic-derived erosion rate into our calculations, we obtain an erosion rate of $31 \pm 2.8 \mathrm{~mm} / \mathrm{ka}$ for the Menderes metamorphic basement in the hanging wall of the Gediz Detachment, and a rate of $93 \pm 8.4 \mathrm{~mm} / \mathrm{ka}$ for the Northern Menderes Massif drained by the Gediz river. Noteworthy, the area undergoing faster short-term erosion is the same area that experienced fast exhumation in the Pliocene (see section 5.1). The erosion rates observed today are far too low to explain the Pliocene cooling-ages of the footwall units, which may be instead ascribed to tectonic exhumation in the footwall of the Gediz Detachment (Buscher et al., 2013).

This article is protected by copyright. All rights reserved. 


\subsection{Constraints on the paleo river network}

Along the modern river trunk, samples display polymodal grain-age distributions. The youngest AFT age population in samples M4 $(11.6+3.4 /-2.7 \mathrm{Ma})$ includes $\sim 35 \%$ of dated grains, whereas in the upstream sample M3 the youngest AFT age population $(14.3+5.4 /-3.9$ Ma) includes $\sim 21 \%$ of dated grains. This percentage is similar to that observed in the uppermost sample of the fossil basin fill (sample F9), collected close to sample M3 and in a similar position within the graben, which shows a young AFT age population at $9.3+3.4 /-2.5$ Ma including $\sim 21 \%$ of dated grains. The polymodal single grain-age distribution observed in samples M3 and F9 (see Fig. 4 and Fig. 6), when compared to the unimodal single grain-age distributions observed in the older samples F8 to F6, suggests that the modern drainage network was already established during the deposition of the Kaletepe Fm, even though we cannot safely exclude that samples F8 to F6 may be exclusively derived from the southern side of the graben because collected too far from the paleo river trunk at the time of Gediz Fm deposition. However, the hypothesis of a drainage reorganization is also supported by the unconformable relationships observed between the Gediz Fm and the overlying Kaletepe Fm and by a major change in the sediment transport direction from transversal ( NNE directed) to longitudinal highlighted by paleocurrent analyses (Çiftçi \& Bozkurt, 2009; Öner \& Dilek., 2011).

The apatite grains dated in samples F8 to F6 were necessarily eroded from an area characterized today by similar or even younger AFT ages as a result of progressive erosional exhumation. The only nearby potential source area for the Gediz Fm is thus represented by units at the southern margin of the basin. The underlying sample F5 additionally includes an older grain-age population at 17.5 +5.1/-3.9 Ma, possibly derived from hanging wall units on the southern side of the graben. Provenance from the northern side of the graben can be safely excluded, because grain-age population observed in modern sediments are older than those observed in sample F5.

Provenance in the lowermost part of the sedimentary succession is more difficult to assess. Only detritus in sample F2 and a small part of the detritus in sample F3, corresponding to the peak at $15.4 \mathrm{Ma}$, can be safely ascribed, in terms of provenance, to the southern part of the graben. All of the other populations in samples F4, F3 and F1 are either consistent with a provenance from the northern side of the graben, or from its southern side.

This article is protected by copyright. All rights reserved. 


\subsection{AFT constraints on the depositional age of the basin fill}

Our dataset provides new constraints on the depositional age of the basin fill. The lowermost samples analyzed in this work (F1 and F2), both belonging to the Alaşehir Fm, yielded unimodal single grain-age distributions and peak ages decreasing upsection, from $29.4 \pm 2.5 \mathrm{Ma}$ to $16.0 \pm 1.4 \mathrm{Ma}$. This trend indicates a negligible post-depositional AFT annealing. As a result, the $16.0 \pm 1.4 \mathrm{Ma}$ age in sample F2 represents the maximum age for the deposition of the sampled layer of the Zeytinçayi member of the Alaşehir Fm. Çiftçi \& Bozkurt (2009) already suggested a middle Miocene age for the deposition of the Alaşehir Fm based on well log data interpretation. These observations are consistent with the activation of extensional detachment tectonics on the Gediz Detachment at $\sim 14.5 \mathrm{Ma}$ (Rossetti et al., 2017). Even though sample F2 was not collected from the very base of the Alaşehir Fm, in the light of these considerations we find reasonable to extend its constrains to the underlying part of the formation. Our results thus improve the existing, but rather weak age constraints based on the palynological association, which suggested a lower-middle Miocene age of 20-14 Ma for the deposition of this formation (Iztan \& Yazman, 1991; Seyitoğlu \& Scott, 1992; Ediger et al., 1996). The maximum stratigraphic age of the Alaşehir Fm can be then bracketed between $16 \pm 1.4$ and 14 Ma.

The lack of post-depositional annealing in the lowermost part of the succession excludes major AFT age rejuvenation also in the overlying formations. Hence, the lower part of the Çaltilik Fm must be younger than the youngest peak found in sample F3 $(15.4+9.1 /$ $5.7 \mathrm{Ma}$ ), whereas its upper part must be necessarily younger than $6.3 \pm 2.2 \mathrm{Ma}$. These new constraints on the Caltilik Fm are remarkable, as the only existing age determination in the literature for these deposits relies on the Eskihisar sporomorph association (20-14 Ma) of Benda \& Meulenkamp $(1979,1990)$. By contrast, our data indicate that the upper part of the Çaltilik Fm cannot be older than the Messinian.

Finally, detrital AFT age data from the Gediz and Kaletepe Fm indicate an age of deposition younger than $6.2 \pm 0.6 \mathrm{Ma}$ for the upper part of the basin fill, which further supports our correlation, based on field evidence, between the lower part of the Gediz Fm and the Göbekli Fm defined by Emre (1996) in the Salihli area, that was ascribed to the MioPliocene boundary (Dacian) (Emre, 1996). 


\subsection{Schematic evolution of the Gediz Graben}

To summarize our results, Fig. 8 schematically illustrates the evolution of the Gediz Graben. Previously published bedrock AFT data (Gessner et al., 2001; Ring et al., 2003; Thompson \& Ring, 2006), together with our detrital ages from the northern modern tributaries, show that the northern margin of the basin was already exhumed during the Oligocene or Early Miocene at the latest, so did not experience further relevant exhumation during the evolution of the graben.

Geophysical data highlighted the undulated nature of the basement of the Gediz Graben (Gürer et al., 2001, 2002), with basement lows and highs alternating along the strike of the basin. Moreover, Çiftçi \& Bozkurt (2010) suggested that the Gediz Graben evolved as three independent sub-basins that eventually linked in post-Miocene times. However, in the evolutionary model in Fig. 8 we decided to schematically represent the Gediz Graben as a laterally continuous sedimentary basin, since despite the different parts of the basin might have experienced lateral differences during sedimentation, this segmentation did not influenced the early stages of exhumation, and the margins of the basin show a coherent along-strike exhumation history until the last Plio-Quaternary more localized exhumation event.

The detrital AFT ages recorded in the lower part of the stratigraphic sequence (i.e. Alaşehir Fm and lower Çaltilik Fm) suggest that the source areas of these deposits were not undergoing major exhumation by the time of the first phases of basin formation (i.e. Middle Miocene: Çiftçi \& Bozkurt, 2009; this study. Fig. 8, STEP 1). The age of this phase is constrained by our new detrital AFT data, and is also consistent with the activation of ductile extensional deformation on the Gediz Detachment at $14.5 \mathrm{Ma}$ (Rossetti et al., 2017). Since there are no evidences for major active high-angle faults bounding the basin during middle Miocene, it is likely that in its early stages the Gediz Graben developed as a ramp-basin (i.e. a sag-like depression reflecting the flat-ramp geometry of the detachment at depth).

During the Late Miocene, a major phase of exhumation involved the southern margin of the basin. This is recorded in the detrital AFT ages of all the upper part of the Neogene-toQuaternary sedimentary sequence (Fig. 8, STEP 2), starting from the middle Çaltilik Fm. This phase corresponds to a major structural and stratigraphic reorganization of the basin that is controlled by the brittle high-angle normal faults bounding the southern margin of the basin

This article is protected by copyright. All rights reserved. 
in a half-graben setting; these structures led to the exhumation of their footwall and produced significant accommodation space at their hanging wall for the deposition of the Caltilik Fm and Gediz Fm between Late Miocene and Pliocene. These normal faults root on a blind detachment shear zone at depth, that at that time was not exposed at the surface yet (e.g. Gessner et al., 2001; Buscher et al., 2013; this study) and was rather deforming under ductile conditions until the Messinian (Lips et al., 2001).

The last exhumation pulse recorded in the southern margin by both bedrock and detrital AFT data (Gessner et al., 2001; Ring et al., 2003; Buscher et al., 2013; this study) occurred during the Late Pliocene - Early Pleistocene and involved only the western part (Salihli area) of the margin, where the Gediz Detachment ductile-to-brittle shear zone is presently exposed as well as rocks at its footwall, including the Lower Miocene Salihli granodiorite (Fig. 8, STEP 3). Also this phase is related to a new major structural and stratigraphic reorganization in the basin, with the activation of normal faults bounding its northern margin and changing its geometry from half-graben into symmetric-graben (Çiftçi \& Bozkurt, 2009). This change is attested by variations in paleocurrent directions between the Neogene sedimentary formations and the unconformably overlaying Kaletepe Fm (Çiftçi \& Bozkurt, 2009; Öner \& Dilek, 2011) and by a reorganization of the drainage pattern highlighted by AFT grain-age distribution in sample F9.

The differential exhumation related to this phase likely produced a differential uplift between the eastern and the western sectors at the southern margin of the Gediz Graben, which is reflected by many present-day features such as topography, short-term erosion pattern and rocks exposed at the surface. The western part of the margin is in fact topographically much higher than the eastern part, with the peaks of the Bozdağ Range located in this area representing the highest elevations reached in the present-day Menderes Massif's topography. Moreover, the short-term erosion pattern (Fig. 8, STEP 3 and supplementary Fig. 1SF) shows higher erosion rates in the Gediz Detachment area, which are likely related to the highest relief produced by the last tectonic event. Basement rocks outcropping in the eastern sector of the basin margin do not show any ductile deformation clearly related to the Neogene extensional phase that generated the basin, thus suggesting that in this portion is exposed a higher crustal level than the in the western sector; finally, in the Alaşehir area are visible in outcrop the oldest sedimentary units of the Gediz Graben fill, which might have been more uplifted in the Salihli area above the Gediz Detachment (as 
nowadays in the Alaşehir area) and then eroded, thus explaining the differences in the outcrop exposure of the stratigraphic sequence between the two sectors (see Fig. 6).

\section{Conclusion}

In this work, our comprehensive detrital AFT approach, combining analysis of modern river sediments, analysis of fossil sedimentary successions, and mineral fertility determinations, allowed to reconstruct the exhumation history of the northern margin of the Central Menderes Massif, the Neogene-to-Present evolution of the Gediz Graben and the modern erosion pattern of the margins of the basin.

The main results can be summarized as follows:

- Three main exhumation events with different spatial relevance have been identified in the study area: i) a Late Oligocene - Early Miocene regional event related to the main exhumation of the whole Menderes Massif; ii) an Late Miocene event localized at the southern margin of the basin, controlled by high-angle normal faults rooting on the detachment and recorded in the Neogene sedimentary fill of the graben; iii) a more localized Plio-Quaternary event that involved only the western part of the southern margin (Salihli area) and brought the Gediz Detachment and its intrusive footwall to the surface in the Bozdağ area.

- The differential uplift related to the latter exhumation event may explain the differential exposure in outcrop of the stratigraphic sequence between the western and eastern sectors of the southern margin of the basin.

- The exhumation pattern at the southern margin of the Gediz Graben supports the hypothesis, based on field observations, that the eastern part of the southern margin (Alasehir area) is at the hanging wall of the Gediz Detachment, which is thus not exposed along the whole strike of the southern basin margin.

- Comparison between past/present and long-term/short-term erosion rates suggest that the major exhumation events during Miocene-to-Quaternary times have been dominantly assisted by tectonic unroofing rather than erosion, as already suggested by Buscher et al. (2013).

- The modern short term erosion pattern closely reflects the Plio-Quaternary localized exhumation event, with erosion rates three times higher in the area of the Gediz Detachment than in the rest of the margins of the Gediz Graben.

This article is protected by copyright. All rights reserved. 
- Detrital AFT ages in the Neogene-to-Quaternary sedimentary succession allowed to refine the maximum age for basin formation to the middle Miocene, and rejuvenate the Çaltilik Fm to the upper Miocene.

- Major reorganizations of the drainage pattern occurred at the transition between the Alaşehir Fm and the Çaltilik Fm and between the Gediz Fm and the Kaletepe Fm. This variations likely correspond to major reorganizations in the architecture of the basin during its evolution.

\section{ACKNOWLEDGMENTS}

The manuscript benefitted from insightful reviews by M.L. Balestrieri, E. Bozkurt and two anonymous reviewers. E. Garzanti and A. Resentini are acknowledged for providing access to laboratory facilities and for technical assistance during sample preparation. S. Özden, O.H. Göğüş, A. Yangöz, S.C. Ülgen and N. Öğretmen are kindly acknowledged for their field assistance.

\section{CONFLICT OF INTEREST}

No conflict of interest declared.

\section{REFERENCES}

Andersen T. (2005) Detrital zircons as tracers of sedimentary provenance: limiting conditions from statistics and numerical simulation. Chemical Geology, 216 (3), 249-270.

Benda L. \& Meulenkamp J.E. (1979) Biostratigraphic correlations in the Eastern Mediterranean Neogene: 5. Calibration of sporomorph associations, marine microfossils and mammal zones, marine and continental stages and radiometric scale. VII International Congress of Mediterranean Neogene, Athens, 61-70.

Benda L. \& Meulenkamp J.E. (1990) Biostratigraphic correlation in the Eastern Mediterranean Neogene, 9. Sporomorph associations and event stratigraphy of the Eastern Mediterranean. Newsletters on Stratigraphy, 23, 1-10.

Bernet, M., Zattin, M., Garver, J.I., Brandon, M.T. \& Vance, J. A. (2001) Steady-state exhumation of the European Alps. Geology, 29, 35-38. 
Bozkurt E. \& Sözbilir H. (2004) Tectonic evolution of the Gediz Graben: field evidence for an episodic, two-stage extension in western Turkey. Geological Magazine, 141, 63-79.

Brandon, M.T. (2002) Decomposition of mixed grain age distributions using Binomfit. On Track, 24, 13-18.

Brewer, I.D., Burbank, D.W., \& Hodges, K.V. (2003) Modelling detrital cooling-age populations: Insights from two Himalayan catchments. Basin Research, 15, 305-320, doi: 10.1046/j.1365-2117.2003.00211.x

Brun, J.P. \& Sokoutis, D. (2007) Kinematics of the southern Rhodope core complex (North Greece). International Journal of Earth Sciences, 96 (6), 1079-1099.

Buscher, J. T., Hampel, A., Hetzel, R., Dunkl, I., Glotzbach, C., Struffert, A., Akal, C. \& Rätz, M. (2013) Quantifying rates of detachment faulting and erosion in the central Menderes Massif (western Turkey) by thermochronology and cosmogenic 10Be. Journal of the Geological Society of London, 170, 669-683.

Carter, A. (1999) Present status and future avenues of source region discrimination and characterization using fission-track analysis. Sedimentary Geology, 124, 31-45.

Çiftçi N.B. \& Bozkurt E. (2008) Folding of the Gediz Graben Fill, SW Turkey: Extensional and/or Contractional Origin? Geodinamica Acta, 21 (3), 145-167, DOI: 10.3166/ga.21.145167

Çiftçi, N.B. \& Bozkurt, E., (2009) Evolution of the Miocene sedimentary fill of the Gediz Graben, SW Turkey. Sedimentary Geology, 216, 49-79.

Çiftçi, N.B. \& Bozkurt, E. (2010) Structural Evolution of the Gediz Graben, SW Turkey: Temporal and Spatial Variation of the Graben Fill. Basin Research, 22, 846-873.

Cohen, H.A., Dart, C.J., Akyüz, H.S. \& Barka, A.A. (1995) Syn-rift sedimentation andstructural development of Gediz and Büyük Menderes graben, western Turkey. Journal of the Geological Society of London, 152, 629-638.

Dunkl, I. (2002) Trackkey: a Windows program for calculation and graphical presentation of fission track data. Computers and Geosciences, 28, 3-12 
Ediger, V.Ş., Batı, Z. \& Yazman, M. (1996) Paleopalynology of possible hydrocarbon source rocks of the Alaşehir-Turgutlu area in the Gediz Graben (western Anatolia). Turkish Association of Petroleum Geologists, 8, 94-112.

Ehlers, T.A. (2005) Crustal thermal processes and the interpretation of thermochronometer data. Reviews in Mineralogy and Geochemistry, 58, 315-350. doi: 10.2138/rmg.2005.58.12.

Emre, T. (1996) Geology and tectonics of Gediz Graben. Turkish Journal of Earth Sciences, $5,171-185$.

Erkül, F., Erkül, S.T., Ersoy, Y., Uysal, I. \& Krötzli, U. (2013) Petrology, mineral chemistry and $\mathrm{Sr}-\mathrm{Nd}-\mathrm{Pb}$ isotopic compositions of granitoids in the central Menderes metamorphic core complex: Constraints on the evolution of Aegean lithosphere slab. Lithos, 180-181, 74-91.

Friedmann, S.J. \& Burbank, D.W. (1995) Rift basins and supradetachment basins: intracontinental extensional end-members. Basin Research, 7, 109-127.

Gallagher, K., Brown, R. \& Johnson, C. (1998) Fission track analysis and its application to geological problems. Annual Reviews Earth Planetary Science, 26, 519-572.

Garver, J.I., Brandon, M.T., Roden-Tice, M. \& Kamp, P.J.J. (1999) Exhumation History of Orogenic Highlands Determined by Detrital Fission-Track Thermochronology. In: Exhumation Processes: Normal Faulting, Ductile Flow and Erosion, Ring, U., Brandon, M.T., Lister, G.S., and Willett, S.D., Eds., Geological Society of London Special Publication, 154, 283-304.

Gessner, K., Ring, U., Johnson, C., Hetzel, R., Passchier, C.W. \& Gungor, T. (2001) An active bivergent rolling-hinge detachment system: Central Menderes metamorphic core complex in western Turkey. Geology, 29, 611-614.

Gessner, K., Gallardo, L.A., Markwitz, V., Ring, U. \& Thomson, S.N. (2013) What caused the denudation of the Menderes Massif: Review of crustal evolution, lithosphere structure, and dynamic topography in southwest Turkey. Gondwana Research, 24(1), 243-274.

Gibbs, A.D. (1984) Structural evolution of extensional basin margins. Journal of the Geological Society of London, 141, 609-620.

Glodny, J. \& Hetzel, R. (2007) Precise U-Pb ages of syn-extensional Miocene intrusions in the central Menderes Massif, western Turkey. Geological Magazine, 144, 235-246.

This article is protected by copyright. All rights reserved. 
Gürer, A., Gürer, Ö.F., Pinçe, A. \& İlkişik, O.M. (2001) Conductivity Structure along the Gediz Graben, West Anatolia, Turkey: Tectonic Implications. International Geology Review, 43, $1129-1144$

Gürer, A., Pinçe, A., Gürer, F. \& İlkişik, O.M. (2002) Resistivity Distribution in the Gediz Graben and its Implications for Crustal Structure. Turkish Journal of Earth Sciences, 11, 1525.

Hetzel, R., Ring, U., Akal, C. \& Troesch, M. (1995) Miocene NNE-directed extensional unroofing in the Menderes massif, southwestern Turkey. Journal of the Geological Society of London, 152, 639-654.

Hurford, A.J. (1990) Standardization of fission-track dating calibration: Recommendation by the Fission Track Working Group of the I.U.G.S.: Subcommission on Geochronology. Chemical Geology, 80, 171-178.

Işik, V., Seyitoğlu, G. \& Çemen, I. (2003) Ductile-brittle transition along the Alas_ehir detachment fault and its structural relationship with the Simav detachment fault, Menderes massif, western Turkey. Tectonophysics, 374, 1-18.

Iztan, H. \& Yazman, M. (1991) Geology and hydrocarbon potential of the Alaşehir (Manisa) area, western Turkey. Proceedings of the International Earth Sciences Congress on Aegean Regions, Izmir, 327-338.

John, B.E. \& Cheadle, M.J. (2010) Deformation and alteration associated with oceanic and continental detachment fault systems: are they similar? In: Diversity of Hydrothermal Systems on Slow Spreading Ocean Ridges. P.A. Rona, C.W. Devey, J. Dyment, and B.J. Murton, eds, Geophysical Monograph Series, 188, 175-205.

Jolivet, L. \& Faccenna, C. (2000) Mediterranean extension and the Africa-Eurasia collision. Tectonics, 19 (6), 1095-1106.

Jolivet, L. \& Brun, J.P. (2010) Cenozoic geodynamic evolution of the Aegean. International Journal of Earth Sciences, 99, 109-138.

Karamanderesi, İ.H. (2013) Characteristics of Geothermal Reservoirs in Turkey. IGA Academy Report 0102-2013, 34 pp.

This article is protected by copyright. All rights reserved. 
Kent, E., Boulton, S.J., Stewart, I.S., Whittaker, A.C. \& Alçiçek, M.C. (2016) Geomorphic and geologic constraints on the active normal faulting of the Gediz (Alaşehir) Graben, Western Turkey. Journal of the Geological Society, London, 173, 666-678.

Koçyiğit, A., Yusufoğlu, H. \& Bozkurt, E. (1999) Evidence from the Gediz Graben for episodic two-stage extension in western Turkey. Journal of the Geological Society of London, 156, 605-616.

Lips, A.L.W., Cassard, D., Sözbilir, H., Yilmaz, H. \& Wijbrans, J.R. (2001) Multistage exhumation of the Menderes Massif, western Anatolia (Turkey). International Journal of Earth Sciences (Geologische Rundschau), 89, 781-792.

Lister, G.S. \& Davis, G.A. (1989) The origin of metamorphic core complexes and detachment faults formed during Tertiary continental extension in the northern Colorado River region, U.S.A. Journal of Structural Geology, 11 (1/2), 65-94.

Malusà, M.G., Villa, I.M., Vezzoli, G. \& Garzanti, E. (2011) Detrital geochronology of unroofing magmatic complexes and the slow erosion of Oligocene volcanoes in the Alps. Earth Planet. Sci. Lett., 301, 324-336. doi:10.1016/j.eps1.2010.11.019.

Malusà, M.G. \& Balestrieri, M.L. (2012) Burial and exhumation across the Alps-Apennines junction zone constrained by fission-track analysis on modern river sands. Terra Nova, 24. doi:10.1111/j.1365-3121.2011.01057.x.

Malusà, M.G., Carter, A., Limoncelli, M., Villa, I.M. \& Garzanti, E. (2013) Bias in detrital zircon geochronology and thermochronometry. Chemical Geology, 359, 90-107.

Malusà, M.G., Resentini, A. \& Garzanti, E. (2016) Hydraulic sorting and mineral fertility bias in detrital geochronology. Gondwana Research, 31, 1-19.

MTA - General Directorate of Mineral Research and Exploration (2002a) 1:500.000 scale geological map of Turkey - IZMIR. MTA, Ankara, Turkey.

MTA - General Directorate of Mineral Research and Exploration (2002B) 1:500.000 scale geological map of Turkey - DENIZLI. MTA, Ankara, Turkey.

Oberhänsli, R., Candan, O. \& Wilke, F. (2010) Geochronological evidence of Pan-African eclogites from the central Menderes Massif, Turkey. Turkish Journal of Earth Sciences, 19, 431-447.

This article is protected by copyright. All rights reserved. 
Öner, Z. \& Dilek, Y. (2011) Supradetachment basin evolution during continental extension: the Aegean province of western Anatolia, Turkey. Geological Society of America Bulletin, 123, 2115-2141.

Platt, J.P., Behr, W.M. \& Cooper, F.J. (2015) Metamorphic core complexes: windows into the mechanics and rheology of the crust. Journal of the Geological Society of London, 172, 927.

Purvis, M. \& Robertson, A.H.F. (2005) Sedimentation of the Neogene-Recent Alaşehir (Gediz) continental graben system used to test alternative tectonic models for western (Aegean) Turkey. Sedimentary Geology, 173, 373-408.

Régnier, J.L., Ring, U., Passchier, C.W., Gessner, K. \& Gungor, T. (2003) Contrasting metamorphic evolution of metasedimentary rocks from the Cine and Selimiye nappes in the Anatolide belt, western Turkey. Journal of Metamorphic Geology, 21, 699-721.

Resentini, A. \& Malusà, M.G. (2012) Sediment budgets by detrital apatite fission-track dating (Rivers Dora Baltea and Arc, Western Alps). Geological Society of America Special Papers, 487, 125-140.

Resentini, A., Malusà, M.G. \& Garzanti, E. (2013) MinSORTING: An Excel® worksheet for modelling mineral grainsize distribution in sediments, with application to detrital geochronology and provenance studies. Computers and Geosciences, 59, 90-97.

Ring, U., Gessner, K., Gungor, T. \& Passchier, C.W. (1999) The Menderes Massif of western Turkey and the Cycladic Massif in the Aegean - do they really correlate? Journal of the Geological Society of London, 156, 3-6.

Ring, U., Willner, A.P. \& Lackmann, W. (2001) Stacking of nappes with unrelated pressuretemperature paths: an example from the Menderes nappes of western Turkey. American Journal of Science, 301, 912-944.

Ring, U., Johnson, C., Hetzel, R. \& Gessner, K. (2003) Tectonic denudation of a Late Cretaceous-Tertiary collisional belt: regionally symmetric cooling patterns and their relation to extensional faults in the Anatolide belt of western Turkey. Geological Magazine, 140, $421-441$.

This article is protected by copyright. All rights reserved. 
Rossetti, F., Asti, R., Faccenna, C., Gerdes, A., Lucci, F. \& Theye, T. (2017) Magmatism and crustal extension: constraining activation of the ductile shearing along the Gediz detachment, Menderes Massif (western Turkey). Lithos, 282-283, 145-162.

Sarıca, N. (2000) The Plio-Pleistocene age of Büyük Menderes and Gediz grabens and their tectonic significance on $\mathrm{N}-\mathrm{S}$ extensional tectonics in West Anatolia: mammalian evidence from the continental deposits. Geological Journal, 35, 1-24.

Şengör, A.M.C. \& Yilmaz, Y. (1981) Tethyan evolution of Turkey: a plate tectonic approach. Tectonophysics, $\mathbf{7 5}, 181-241$.

Şengör, A.M.C., Satir, M. \& Akkök, R. (1984) Timing of the tectonic events in the Menderes massif, western Turkey: implications for tectonic evolution and evidence for Pan- African basement in Turkey. Tectonics, 3, 693-707.

Şengör, A.M.C. (1987) Cross faults and differential stretching of hangingwalls in regions of low-angle normal faulting: examples from Western Turkey. In: Coward, M.P.,Dewey, J.F., Hancock, P.L. (Eds.), Continental Extensional Tectonics, 575-589.

Seyitoğlu, G. \& Scott, B.C. (1992) The age of the Büyük Menderes graben (west Turkey) and its tectonic implications. Geological Magazine, 129, 239-242.

Seyitoğlu, G. \& Scott, B.C. (1996) The cause of N-S extensional tectonics in western Turkey: tectonic escape vs back-arc spreading vs orogenic collapse. Journal of Geodynamics, 22, 145-153.

Seyitoğlu, G., Tekeli, O., Çemen, İ., Şen, Ş. \& Işık, V. (2002) The role of flexural rotation/rolling hinge model in the tectonic evolution of the Alaşehir Graben, western Turkey. Geology Magazine, 139, 15-26.

Seyitoğlu G., Işik V. \& Esat K. (2015) A 3D model for the formation of turtleback surfaces: the Horzum Turtleback of western Turkey as a case study. Turkish Journal of Earth Sciences, 23, 479-494.

Sözbilir H., (2001) Extensional tectonics and the geometry of related macroscopic structures: Field evidence from the Gediz detachment, western Turkey. Turkish Journal of Earth Sciences, 10, 51-67.

This article is protected by copyright. All rights reserved. 
Thomson, S.N. \& Ring, U. (2006) Thermochronologic evaluation of post-collision extension in the Anatolide Orogen, western Turkey. Tectonics, 25, TC3005.

Van Hinsbergen, D.J.J. \& Meulenkamp, J.E. (2006) Neogene supradetachment basin development on Crete (Greece) during exhumation of the South Aegean core complex. Basin Research, 18, 103-124. doi: 110.1111/j.1365-2117.2005.00282.x

Vermeesch, P. (2004) How many grains are needed for a provenance study? Earth and Planetary Science Letters, 224 (3), 441-451.

Vermeesch, P. (2009) RadialPlotter: a Java application for fission track, luminescence and other radial plots. Radiation Measurements, 44 (4), 409-410.

Whitney, D.L., Teyssier, C., Rey, P. \& Buck, W.R. (2013) Continental and oceanic core complexes. Geological Society of America Bulletin, 125 (3/4), 273-298.

Yılmaz, Y., Genç, S.C., Gürer, Ö.F., Bozcu, M., Yılmaz, K., Karacık, Z., Altunkaynak, Ş. \& Elmas, A. (2000) When did western Anatolian grabens begin to develop. In: Tectonics and Magmatism in Turkey and the Surrounding Area, Bozkurt, E.,Winchester, J.A., Piper, J.D.A. (Eds.), Geological Society of London Special Publications, 173, p. 353-384.

Zlatkin, O., Avigad, D. \& Gerdes, A. (2013) Evolution and provenance of Neoproterozoic basement and Lower Paleozoic siliciclastic cover of the Menderes Massif (western Taurides): Coupled U-Pb-Hf zircon isotope geochemistry. Gondwana Research, 23, 682-700.

\section{Figure captions}

Figure 1: Tectonic map of SW Turkey showing the main grabens within the Menderes Massif, and sketch map of the Eastern Mediterranean (inset). Acronyms: NAF, North Anatolian Fault; EAF, East Anatolian Fault; DSF, Dead Sea Fault; HA, Hellenic Arc; CA, Cyprean Arc. Redrawn and modified after 1:500.000 scale geological map of Turkey, Izmir and Denizli sheets (MTA, 2002a,b); subdivision of the structural nappes after Gessner et al. (2013).

This article is protected by copyright. All rights reserved. 
Figure 2: Geological map of the study area (see Fig. 1 for location) with location of the detrital samples used for AFT analysis.

Figure 3: a) Shaded relief image of the study area (see location in Fig. 1) with analyzed samples from modern rivers in this study and literature bedrock AFT data (in Ma) on bedrock samples (from Gessner et al., 2001; Ring et al., 2003; Thomson \& Ring, 2006; Buscher et al., 2013): yellow dots indicate bedrock AFT (literature) from the hanging wall of the Gediz detachment; red dots indicate bedrock AFT (literature) from the footwall of the Gediz detachment; blue dots indicate the location of samples from modern rivers analyzed in this study. b) Block diagram and stratigraphic succession of the Gediz Graben showing the location of analyzed samples and the average apatite fertility values measured in the hanging wall and footwall units.

Figure 4: Radial plots showing the downstream changes of the apatite fission track single grain-age distribution for the modern rivers' detrital samples. Red lines indicate the grain-age populations (in Ma) after deconvolution using the software Binomfit (Brandon, 2002). Numbers in brackets (for polymodal samples with $\mathrm{P}(\%)<5$ ) indicate the size of the smallest population fraction that we can be $95 \%$ certain that was not missed under the hypotheses of Andersen (2005) and Vermeesch (2004).

Figure 5: Along-strike cross section along the southern margin of the Gediz Graben with single grain-age trend observed across the Gediz detachment in modern sand samples collected on the southern side of the Gediz Graben (same data as in Fig. 4). The youngest exhumation event, attested by the red bells, is only recorded in the footwall of the Gediz Detachment. See SF1 in Supplementary materials for the location of the trace of the cross section.

Figure 6: Stratigraphy of the southern margin of the Gediz Graben and radial plots reporting the single grain-age distributions of the analyzed samples from the Neogene-to-Quaternary sedimentary sequence (F1-9). Red lines indicate the grain-age populations after 
deconvolution using the software Binomfit (Brandon, 2002). Numbers in brackets (for polymodal samples with $\mathrm{P}(\%)<5)$ indicate the size of the smallest population fraction that we can be $95 \%$ certain that was not missed under the hypotheses of Andersen (2005) and Vermeesch (2004). Please note that the stratigraphic columns represent the portions of the stratigraphic sequence that are presently exposed in outcrop in the two sectors of the southern margin of the basin, which do not necessarily coincide with the complete stratigraphy preserved in the distal part of the graben.

Figure 7: Trend of grain-age peaks along the Neogene-to-Quaternary stratigraphic succession (data as in Fig. 6). Major peaks get younger up section within each formation, as expected, and provenance changes between different formations are recorded by the addition of older sets of peaks. The red bells first appearing in the upper Çaltilik Fm. mark the Late Miocene (Tortonian-Messinian) exhumation event.

Figure 8: Schematic block-diagram showing the geologic evolution of the Gediz Graben since the beginning of the formation of the basin. STEP 1 - Middle Miocene: no major exhumation event at the basin margins is unveiled by detrital samples in the Alaşehir and lower Çaltilik Fms, which record instead older events affecting the Menderes metamorphic basement; sediment provenance is likely from the southern margin, and possibly from the northern margin of the basin. STEP 2 - Late Miocene: a major exhumation phase affecting the southern margin of the basin is recorded in the upper Çaltilik and Gediz Fms; during this phase, detrital contribution are exclusively from the southern margin of the basin. STEP 3 Late Pliocene to Present: the present-day drainage pattern is established at this stage; in the southern margin of the basin, exhumation is slower in the eastern part than in the western part, including the footwall of the Gediz Detachment and the Salihli granodiorite; modern erosion rates show the same pattern, but lower magnitude, indicating that exhumation was probably dominated by tectonic unroofing rather than erosion. Keys: thin blue lines with arrows indicate sediment provenance in each step (dashed when uncertain); large white arrows indicate long-term exhumation rates; yellow arrows indicate modern short-term erosion rates (arrow length according to rates). In STEP 3, exhumation rates are averaged over the last $\sim 2 \mathrm{Myr}$ in the footwall and the last $\sim 9 \mathrm{Myr}$ in the hanging wall (see section 5.1). 


\section{Table captions}

Table 1: Location of the analyzed samples.

Table 2: Apatite fertility in samples from the main river's tributaries.

Table 3: Results of AFT counting. Ages are calculated with the External Detector Method (Hurford, 1990). Value of the $\mathrm{Z}$ parameter of the analyst (R. Asti): $302.28 \pm 18.12$. Rho-s, spontaneous track density ( $\times 10^{5}$ tracks per $\left.\mathrm{cm}^{2}\right)$; Ns, number of spontaneous tracks counted; Rho-i, induced track density in external detector $\left(x 10^{5}\right.$ tracks per $\left.\mathrm{cm}^{2}\right)$; Ni, number of induced tracks counted; Rho-d, induced track density in external detector adjacent to dosimeter glass $\left(\mathrm{x} 10^{5}\right.$ tracks per $\left.\mathrm{cm}^{2}\right)$. These data were used to calculate AFT ages with the zeta calibration method.

Table 4: Apatite grain-age populations of samples from the modern Alaşehir/Gediz river (M1-5), its southern (SX1-5) and northern (DX1-3) tributaries and from the Neogene-toQuaternary sedimentary succession of the Gediz Graben (F1-9); age and error are expressed in Ma.

\section{Supplementary figure captions}

Supplementary Figure 1SF: Apatite fertility map and short term erosion pattern of the study area (the size of the cubes is proportional to the relative (nondimensional) short-term erosion rate of each subarea). Red line show the location of the schematic cross-section in Fig. 4.

Supplementary Figure 2SF: Dense Mineral Concentration (left) and Grain Density values (right) in samples from the northern (DX) and southern (SX) tributaries of the main river. Dense Mineral Concentration is always $<10 \%$ and Grain Density is always $<2.70 \mathrm{Kg} / \mathrm{dm} 3$ : 
these values show that the analyzed samples are not affected by anomalous enrichment of dense minerals due to hydraulic effects during transport.

Supplementary Figure 3SF: Diagrams showing the relationship between AFT grain-ages and grain size (top) and between AFT grain-ages and grain shape (bottom) in the detrital samples collected in the modern rivers. No apparent correlation raised in the correlation between these parameters, showing that the single grain-age distributions are not vulnerable to hydraulic sorting effects.

\section{Supplementary table captions}

Supplementary Table 1ST: Fertility values, detrital apatite partitioning and drainage areas for samples from the modern Alaşehir/Gediz river used for modern short-term erosion pattern determination (see Supplementary Fig. 1SF).

\begin{tabular}{|c|c|c|c|c|c|c|}
\hline Sample & Lab Code & River & Site & Lat. & Long. & Alt. (a.s.I.) \\
\hline M1 & DTR6 & Alaşehir & Bağlica & N 38 $18^{\prime} 09.9^{\prime \prime}$ & E $28^{\circ} 39^{\prime} 27.2^{\prime \prime}$ & $175 \mathrm{~m}$ \\
\hline M2 & DTR7 & Alaşehir & Şendurak & N 38 $28^{\circ} 04.6^{\prime \prime}$ & E $28^{\circ} 27^{\prime} 55.4^{\prime \prime}$ & $128 \mathrm{~m}$ \\
\hline M3 & DTR8 & Alaşehir & Yeşilova & N $38^{\circ} 28^{\prime} 37.8^{\prime \prime}$ & E $28^{\circ} 18^{\prime} 09.1^{\prime \prime}$ & $107 \mathrm{~m}$ \\
\hline M4 & DTR9 & Alaşehir & Salihli & N 38 30' 29.6" & E $28^{\circ} 09^{\prime} 02.7^{\prime \prime}$ & $89 \mathrm{~m}$ \\
\hline M5 & DTR13 & Gediz & Yeniharmandali & N 38 $38^{\circ} 22.4^{\prime \prime}$ & E $27^{\circ} 32^{\prime} 32.6^{\prime \prime}$ & $31 \mathrm{~m}$ \\
\hline SX1 & DTR1 & S tributary & Kestanelik & N 38 $16^{\circ} 18.9^{\prime \prime}$ & E $28^{\circ} 22^{\prime} 53.2^{\prime \prime}$ & $1147 \mathrm{~m}$ \\
\hline$S \times 2$ & DTR2 & S tributary & Karadağ & N $38^{\circ} 21^{\prime} 09.0^{\prime \prime}$ & E $28^{\circ} 18^{\prime} 43.2^{\prime \prime}$ & $586 \mathrm{~m}$ \\
\hline SX3 & DTR3 & S tributary & Karadut & N 38 $28^{\circ} 45.2^{\prime \prime}$ & E $28^{\circ} 17^{\prime} 25.2^{\prime \prime}$ & $423 \mathrm{~m}$ \\
\hline SX4 & DTR5 & S tributary & Çatak & N 38 $24^{\circ} 00.6^{\prime \prime}$ & E $28^{\circ} 13^{\prime} 25.9^{\prime \prime}$ & $769 \mathrm{~m}$ \\
\hline SX5 & DTR4 & S tributary & Damatli & N $38^{\circ} 25^{\prime} 13.7^{\prime \prime}$ & E $28^{\circ} 12^{\prime} 27.4^{\prime \prime}$ & $572 \mathrm{~m}$ \\
\hline DX1 & DTR12 & $\mathrm{N}$ tributary & Türkmen & N 38 $25^{\circ} 58.3^{\prime \prime}$ & E $28^{\circ} 32^{\prime} 01.1^{\prime \prime}$ & $212 \mathrm{~m}$ \\
\hline $\mathrm{DX} 2$ & DTR11 & $\mathrm{N}$ tributary & Matarli & N 38 $24^{\circ} 41.9^{\prime \prime}$ & E $28^{\circ} 30^{\prime} 03.0^{\prime \prime}$ & $166 \mathrm{~m}$ \\
\hline DX3 & DTR10 & $\mathrm{N}$ tributary & Gülpinar & N 38 $29^{\circ} 50.0^{\prime \prime}$ & E $28^{\circ} 26^{\prime} 13.8^{\prime \prime}$ & $346 \mathrm{~m}$ \\
\hline F1 & ALA04 & Alaşehir Fm. & Güldere & N 38 $18^{\circ}$ '51.8" & E $28^{\circ} 26^{\prime} 18.2^{\prime \prime}$ & $919 \mathrm{~m}$ \\
\hline $\mathrm{F} 2$ & DTR ALA1 & Alaşehir Fm. & Güldere & N $38^{\circ} 18^{\prime} 49.4^{\prime \prime}$ & E $28^{\circ} 26^{\prime} 15.8^{\prime \prime}$ & $936 \mathrm{~m}$ \\
\hline F3 & DTR CAT2 & Çaltilik Fm. & Soğukyurt & N $38^{\circ} 21^{\prime} 16.4^{\prime \prime}$ & E $28^{\circ} 24^{\prime} 15.2^{\prime \prime}$ & $711 \mathrm{~m}$ \\
\hline $\mathrm{F} 4$ & DTR CAT1 & Çaltilik Fm. & Soğukyurt & N $38^{\circ} 21^{\prime} 16.4^{\prime \prime}$ & E $28^{\circ} 24^{\prime} 15.2^{\prime \prime}$ & $711 \mathrm{~m}$ \\
\hline F5 & DTR RED2b & Çaltilik Fm. & Kocayar & N 38 $26^{\circ} 18.4^{\prime \prime}$ & E $28^{\circ} 14^{\prime} 59.1^{\prime \prime}$ & $204 \mathrm{~m}$ \\
\hline F6 & DTR RED1 & Çaltilik Fm. & Degirmendere & N 38 $24^{\circ} 48.2^{\prime \prime}$ & E $28^{\circ} 17^{\prime} 55.2^{\prime \prime}$ & $360 \mathrm{~m}$ \\
\hline F7 & DTR YEL1 & Gediz Fm. & Kocayar & N 38 $26^{\circ} 19.5^{\prime \prime}$ & E $28^{\circ} 15^{\prime} 04.4^{\prime \prime}$ & $228 \mathrm{~m}$ \\
\hline F8 & DTR YEL2 & Gediz Fm. & Kocayar & N 38 $26^{\circ} 33.7^{\prime \prime}$ & E $28^{\circ} 15^{\prime} 09.6^{\prime \prime}$ & $225 \mathrm{~m}$ \\
\hline F9 & DTR YEL3 & Kaletepe Fm. & Erendali & N $38^{\circ} 26^{\prime} 42.8^{\prime \prime}$ & E $28^{\circ} 17^{\prime} 40.0^{\prime \prime}$ & $202 \mathrm{~m}$ \\
\hline
\end{tabular}

This article is protected by copyright. All rights reserved. 


\begin{tabular}{|c|c|c|c|c|c|c|c|c|c|c|c|c|c|c|}
\hline \multirow[b]{3}{*}{ Sample } & \multirow[b]{3}{*}{ River } & \multirow[b]{3}{*}{ Site } & \multirow{3}{*}{$\begin{array}{c}\text { Drainage Area } \\
\qquad\left(\mathrm{km}^{2}\right)\end{array}$} & \multirow{2}{*}{\multicolumn{3}{|c|}{ Textural parametrs }} & \multirow{3}{*}{$\begin{array}{c}\text { selected } \\
\text { window } \\
(\mu \mathrm{m})\end{array}$} & \multirow{3}{*}{$\begin{array}{c}\text { relative } \\
\text { amount } \\
(\%)\end{array}$} & \multirow{3}{*}{$\begin{array}{c}\text { dense } \\
\text { mineral } \\
(\%)\end{array}$} & \multirow{3}{*}{$\begin{array}{c}\text { grain } \\
\text { density } \\
\left(\mathrm{kg} / \mathrm{dm}^{3}\right)\end{array}$} & \multicolumn{3}{|c|}{ Apatite size distribution } & \multirow{3}{*}{$\begin{array}{c}\text { Apatite } \\
\text { Fertility } \\
>63 \mu \mathrm{m} \\
(\mathrm{ppm})\end{array}$} \\
\hline & & & & & & & & & & & coarser & in selected & finer & \\
\hline & & & & $\begin{array}{c}\text { mean size } \\
\text { (phi) }\end{array}$ & $\begin{array}{l}\text { sorting } \\
\text { (phi) }\end{array}$ & $\begin{array}{l}\text { skewness } \\
\text { (phi) }\end{array}$ & & & & & & $\begin{array}{c}\text { window } \\
(\%)\end{array}$ & (\%) & \\
\hline SX1 & Kestanelik & Kestanelik & 7 & 2,63 & 1,26 & $-0,06$ & $63-500$ & 61,47 & 1,3 & 2,59 & 7,3 & 78,5 & 14,2 & 312,0 \\
\hline sX2 & Ozan & Karadağ & 56 & 2,40 & 1,27 & $-0,05$ & $63-500$ & 55,55 & 1,8 & 2,61 & 10,2 & 78,9 & 11 & 734,0 \\
\hline SX3 & Dariyeri & Karadut & 21 & 1,70 & 0,98 & 0,19 & $125-500$ & 28,97 & 1,4 & 2,62 & 2,2 & 70,7 & 16,7 & 179,0 \\
\hline SX4 & Kisik & Çatak & 17 & 2,50 & 1,20 & $-0,14$ & $63-500$ & 56,56 & 0,6 & 2,50 & 6,6 & 80,7 & 11,6 & 259,0 \\
\hline sX5 & Karanohut & Damatli & 28 & 1,90 & 1,14 & 0,04 & $125-500$ & 41,66 & 0,8 & 2,63 & 15,9 & 63,2 & 20,9 & 120,0 \\
\hline $\mathrm{DX} 1$ & - & Türkmen & 31 & 2,57 & 1,24 & $-0,11$ & $63-500$ & 59,34 & 4,5 & 2,60 & 7,6 & 79,2 & 13,1 & 563,0 \\
\hline DX2 & - & Matarli & 29 & 1,83 & 0,85 & $-0,08$ & $125-500$ & 40,59 & 5,0 & 2,69 & 10,2 & 77,5 & 12,2 & 569,0 \\
\hline DX3 & Sarikaya & Gülpinar & 22 & 2,00 & 1,42 & $-0,11$ & $63-500$ & 49,79 & 9,1 & 2,64 & 19,5 & 72,4 & 8,1 & 577,0 \\
\hline
\end{tabular}

This article is protected by copyright. All rights reserved. 


\begin{tabular}{|c|c|c|c|c|c|c|c|c|c|c|c|}
\hline Sample & Lab Code & $\mathbf{N}^{\circ}$ Crystals & Rho-s & Ns & Rho-i & Ni & Rho-d & Central Age $\mathbf{( \pm 1 \sigma )}$ & $\mathbf{X}^{\mathbf{2}}$ & $\mathbf{P}(\%)$ & $\mathbf{U}(\mathbf{p p m})$ \\
\hline M1 & DTR6 & 30 & 6,914 & 233 & 20,267 & 683 & 10,76 & $55.3 \pm 5.4$ & 18,7 & 92,87 & 29,72 \\
M2 & DTR7 & 31 & 5,093 & 412 & 18,171 & 1470 & 9,49 & $39 \pm 4.4$ & 81,73 & 0 & 29,6 \\
M3 & DTR8 & 96 & 3,205 & 585 & 19,326 & 3527 & 10,82 & $27.8 \pm 2.3$ & 128,33 & 1,29 & 26,25 \\
M4 & DTR9 & 99 & 2,751 & 603 & 17,705 & 3881 & 10,62 & $27.4 \pm 2.6$ & 249,14 & 0 & 23,27 \\
M5 & DTR13 & 99 & 3,298 & 984 & 17,587 & 5248 & 10,09 & $30.1 \pm 2.5$ & 213,81 & 0 & 25,87 \\
SX1 & DTR1 & 39 & 1,837 & 252 & 17,784 & 2440 & 10,56 & $19.2 \pm 2.4$ & 114,16 & 0 & 26,96 \\
SX2 & DTR2 & 39 & 2,818 & 445 & 24,224 & 3825 & 11,36 & $26 \pm 2.4$ & 403,64 & 0 & 32,93 \\
SX3 & DTR3 & 30 & 1,127 & 146 & 10,054 & 1303 & 10,42 & $34.4 \pm 7.1$ & 271,74 & 0 & 12,28 \\
SX4 & DTR5 & 33 & 0,114 & 34 & 11,853 & 3537 & 11,29 & $2 \pm 0.5$ & 79,78 & 0 & 17,67 \\
SX5 & DTR4 & 27 & 2,384 & 293 & 67,836 & 8337 & 10,36 & $6.9 \pm 1.6$ & 436,21 & 0 & 99,99 \\
DX1 & DTR12 & 30 & 1,804 & 206 & 8,835 & 1009 & 10,29 & $32.4 \pm 3.4$ & 30,64 & 38,24 & 10,27 \\
DX2 & DTR11 & 29 & 2,722 & 494 & 10,623 & 1928 & 10,89 & $42.7 \pm 4.3$ & 74,75 & 0 & 12,69 \\
DX3 & DTR10 & 15 & 2,271 & 57 & 5,299 & 133 & 10,69 & $68.9 \pm 11.7$ & 7,58 & 90,99 & 6,89 \\
F1 & ALA04 & 100 & 1,849 & 343 & 10,496 & 1947 & 11,02 & $29.4 \pm 2.5$ & 82,81 & 87,95 & 14,92 \\
F2 & DTR ALA1 & 80 & 1,682 & 293 & 17,687 & 3081 & 11,09 & $16 \pm 1.4$ & 72,67 & 67,89 & 23 \\
F3 & DTR CAT2 & 99 & 4,227 & 749 & 23,499 & 4164 & 11,22 & $31.9 \pm 2.7$ & 205,02 & 0 & 33,04 \\
F4 & DTR CAT1 & 98 & 2,899 & 396 & 18,997 & 2595 & 10,49 & $24.5 \pm 2$ & 96,28 & 50,15 & 30,31 \\
F5 & DTR RED2b & 100 & 0,856 & 292 & 12,595 & 4295 & 10,96 & $12.2 \pm 1.2$ & 172,02 & 0 & 15,5 \\
F6 & DTR RED1 & 100 & 0,401 & 113 & 9,524 & 2682 & 10,02 & $6.4 \pm 0.7$ & 101,43 & 41,35 & 14,11 \\
F7 & DTR YEL1 & 96 & 0,59 & 173 & 16,22 & 4759 & 11,16 & $6.2 \pm 0.6$ & 100,99 & 31,78 & 18,55 \\
F8 & DTR YEL2 & 99 & 0,727 & 208 & 12,821 & 3668 & 10,22 & $9.6 \pm 1$ & 129,63 & 1,79 & 17,1 \\
F9 & DTR YEL3 & 99 & 2,551 & 918 & 20,975 & 7549 & 10,16 & $20.3 \pm 1.7$ & 241,76 & 0 & 29,2 \\
\hline
\end{tabular}

This article is protected by copyright. All rights reserved. 


\begin{tabular}{|c|c|c|c|c|c|c|c|c|c|}
\hline Sample & Age & Error & $\%$ & Age & Error & $\%$ & Age & Error & $\%$ \\
\hline & \multicolumn{3}{|c|}{$1^{\text {st }}$ population } & \multicolumn{3}{|c|}{$2^{\text {nd }}$ population } & \multicolumn{3}{|c|}{$3^{\text {rd }}$ population } \\
\hline SX1 & 9.3 & $3.3 /-2.4$ & 44.5 & 25.5 & $9.1 /-6.7$ & 47.6 & 47.6 & 23.5/-15.7 & 7.9 \\
\hline $\mathrm{SX} 2$ & 6.4 & $2.2 /-1.6$ & 44.5 & 40.8 & $7.3 /-6.2$ & 55.5 & - & - & - \\
\hline SX3 & 3.8 & $2.4 /-1.5$ & 31.4 & 32.2 & $13.9 /-9.7$ & 42.4 & 110.4 & $56.3 /-37.4$ & 26.2 \\
\hline SX4 & 0.5 & $1 /-0.3$ & 61 & 4.8 & $4.1 /-2.2$ & 39 & - & - & - \\
\hline SX5 & 2.4 & $0.6 /-0.5$ & 69.8 & 16.7 & $3.6 /-3$ & 30.2 & - & - & - \\
\hline DX1 & 26.8 & $10 /-7.3$ & 62.6 & 44.1 & 23.7/-15.4 & 37.4 & - & - & - \\
\hline DX2 & 35.7 & $6.8 /-5.7$ & 82.8 & 80.8 & $27.5 /-20.6$ & 17.2 & - & - & - \\
\hline DX3 & 68.9 & \pm 11.7 & 100 & - & - & - & - & - & - \\
\hline M1 & 55.2 & \pm 5.4 & 100 & - & - & - & - & - & - \\
\hline $\mathrm{M} 2$ & 33 & $8.1 /-6.5$ & 83.2 & 74.9 & $31.6 /-22.3$ & 16.8 & - & - & - \\
\hline M3 & 14.3 & $5.4 /-3.9$ & 20.9 & 32.2 & $5.9 /-5$ & 79.1 & - & - & - \\
\hline M4 & 11.6 & $3.4 /-2.7$ & 35.4 & 37.5 & $7.1 /-6$ & 64.6 & - & - & - \\
\hline M5 & 6.6 & $5.7 /-3$ & 4.6 & 26.1 & $5.7 /-4.7$ & 70.5 & 48.8 & $19.3 /-13.8$ & 24.9 \\
\hline F1 & 29.4 & \pm 2.5 & 100 & - & - & - & - & - & - \\
\hline $\mathrm{F} 2$ & 16 & \pm 1.4 & 100 & - & - & - & - & - & - \\
\hline F3 & 15.4 & $9.1 /-5.7$ & 18.2 & 32.1 & $6.9 /-5.7$ & 74.4 & 84.5 & $35.1 /-24.9$ & 7.3 \\
\hline F4 & 24.5 & \pm 2 & 100 & - & - & - & - & - & - \\
\hline F5 & 6.3 & $2.6 /-1.8$ & 45 & 17.5 & $5.1 /-3.9$ & 55 & - & - & - \\
\hline F6 & 6.4 & \pm 0.7 & 100 & - & - & - & - & - & - \\
\hline F7 & 6.2 & \pm 0.6 & 100 & - & - & - & - & - & - \\
\hline F8 & 7.4 & $6.3 /-3.4$ & 77.5 & 17.3 & $31.8 /-11.2$ & 22.5 & - & - & - \\
\hline F9 & 9.3 & $3.4 /-2.5$ & 23.3 & 21.1 & $5.5 /-4.3$ & 61.3 & 36.2 & $19.8 /-12.8$ & 15.4 \\
\hline
\end{tabular}

This article is protected by copyright. All rights reserved. 


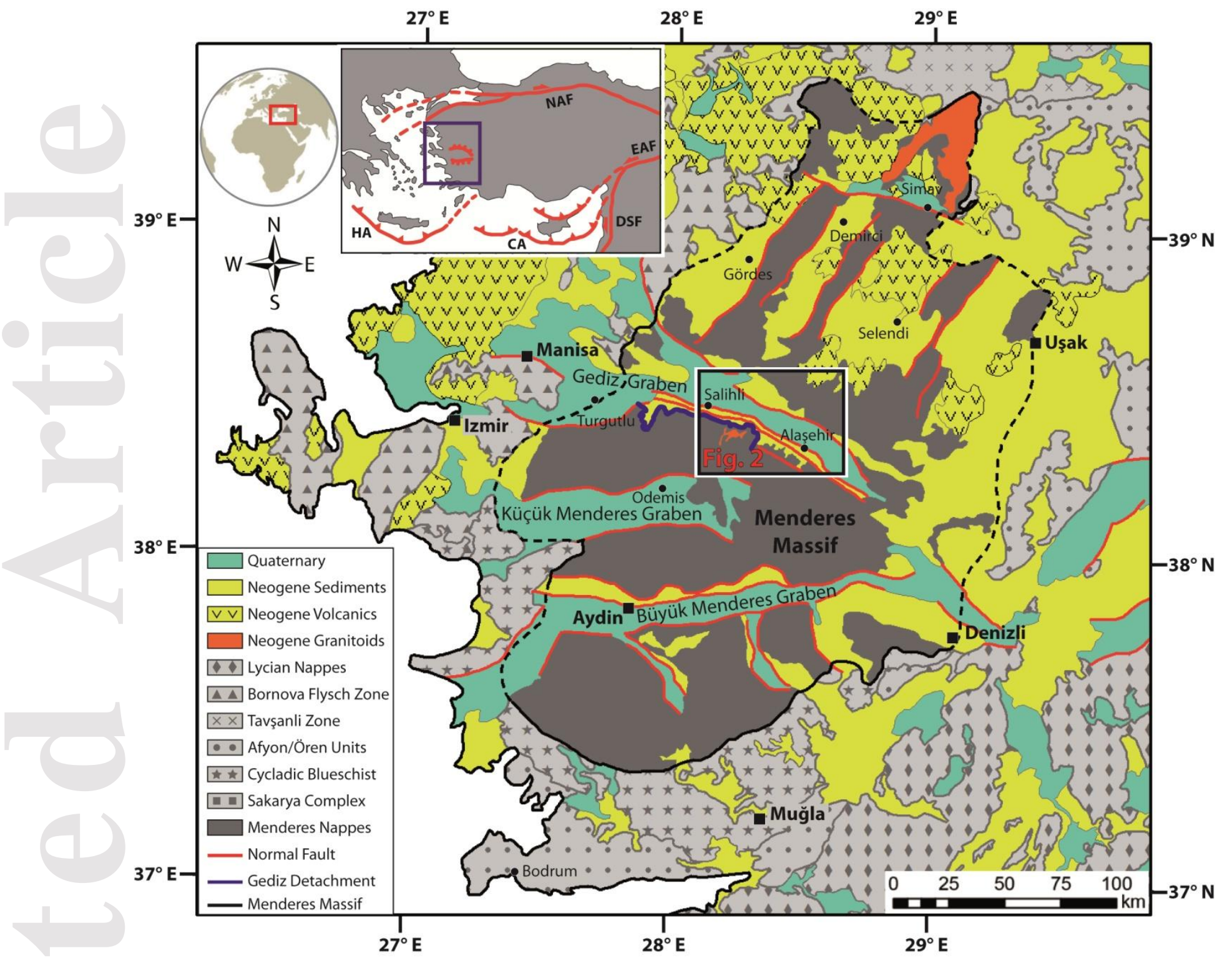

This article is protected by copyright. All rights reserved. 


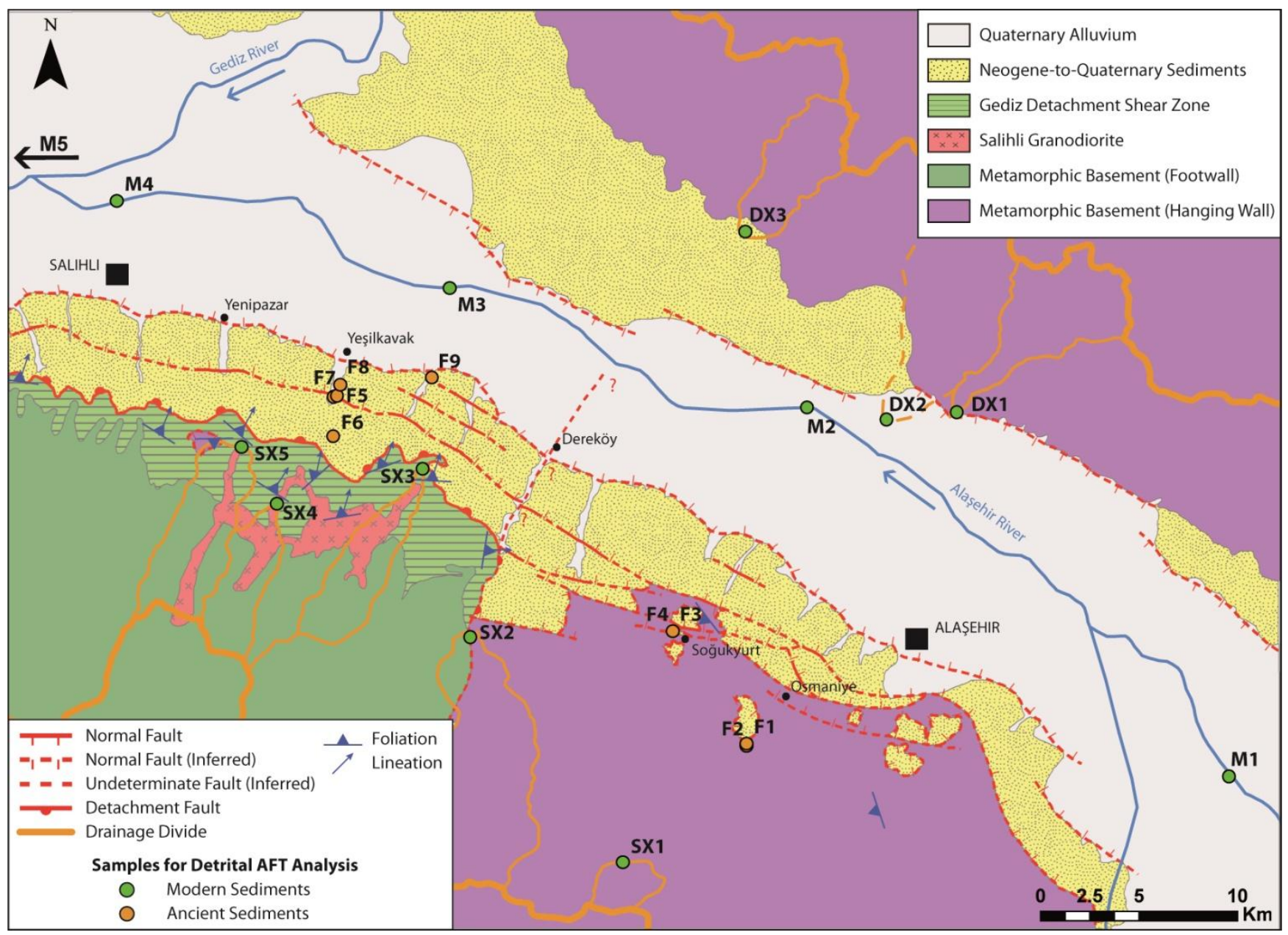

This article is protected by copyright. All rights reserved. 


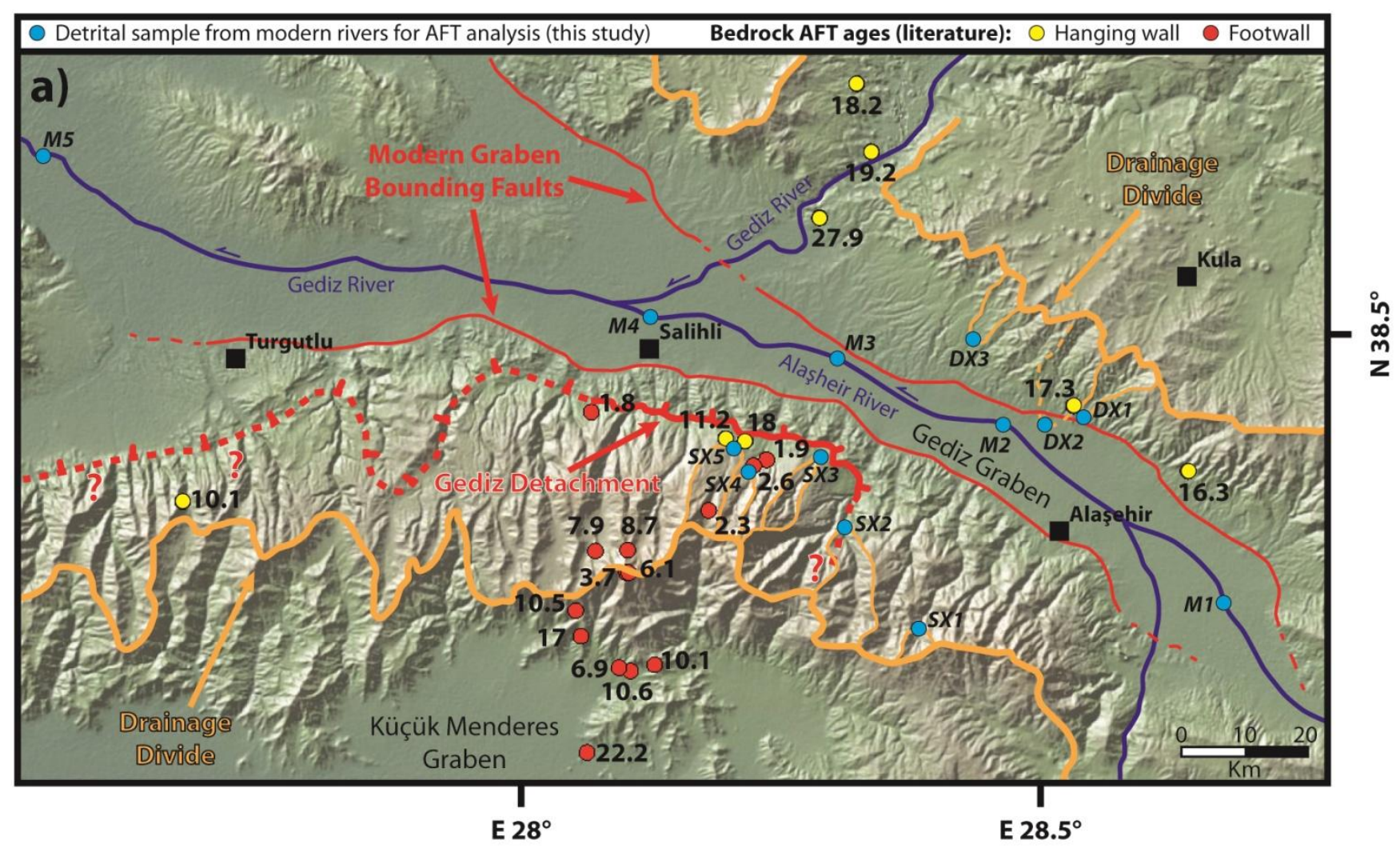

\section{b)}

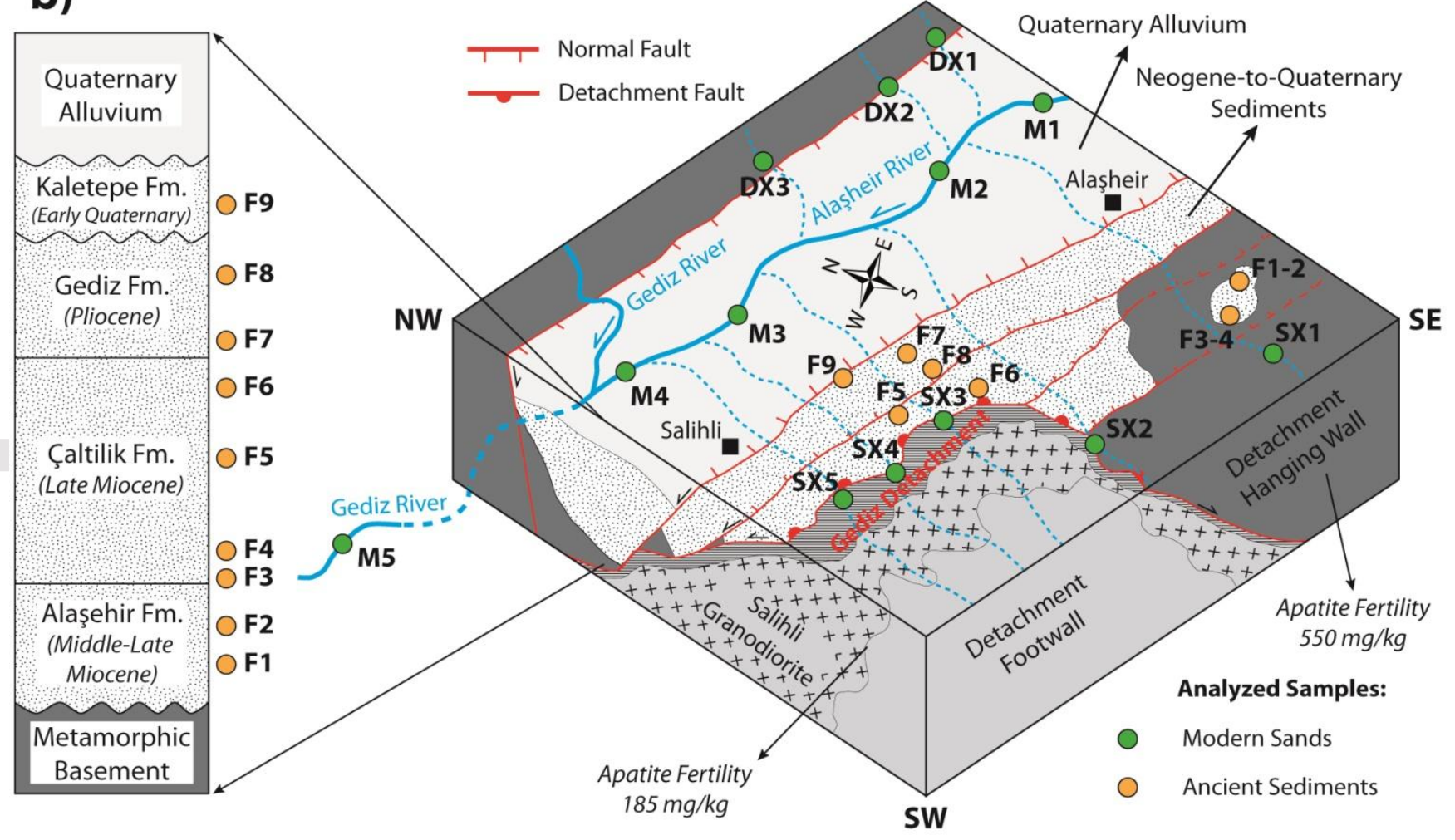

This article is protected by copyright. All rights reserved. 
Northern Tributaries

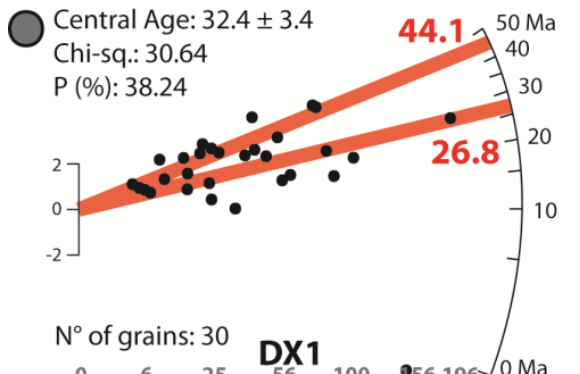

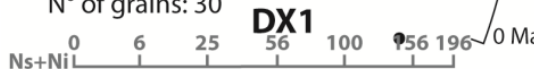

Central Age: $42.7 \pm 4.3 \quad 80.8 \quad 50 \mathrm{Ma}$

Chi-sq.: 74.75

$\mathrm{P}(\%): 0.0$

$(10 ; 16)$
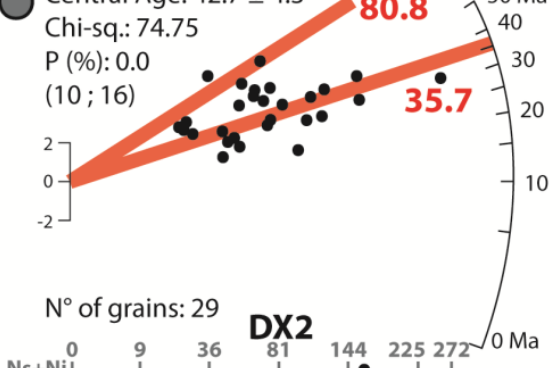

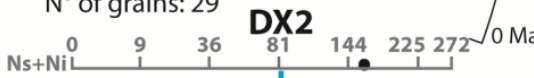

Central Age: $68.9 \pm 11.7$

Chi-sq.: 7.58

P (\%): 90.99
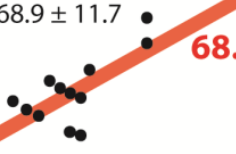

$68.97^{50} \mathrm{M}$
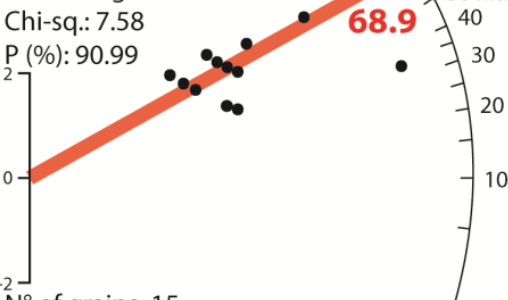

$\mathrm{N}^{\circ}$ of grains: 15

$\mathrm{Ns}+\mathrm{N}$

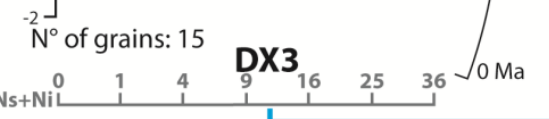

2.4 Grain-age populations (Ma)

Tributary draining the footwall of the Gediz Detachment

Tributary draining the hanging wall of the Gediz Detachment

Tributary draining both the footwall and the hanging wall of the Gediz Detachment
Central Age: $55.3 \pm 5.4$

Chi-sq.: 18.7

P (\%): 92.87

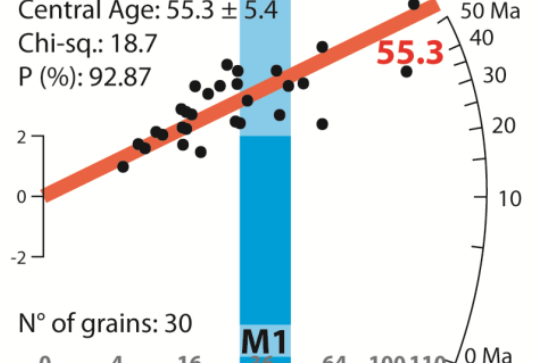

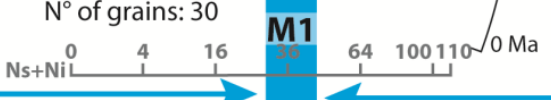

Central Age: $39 \pm 4.4$

Chi-sq.: 81.73

$\mathrm{P}(\%): 0.0$

$(9 ; 15)$

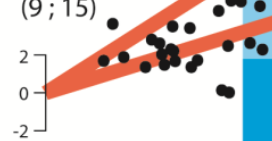

No

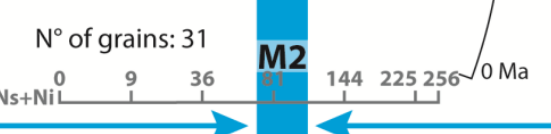

Central Age: $27.8 \pm 2.3$

Chi-sq.: 128.33

$\mathrm{P}(\%): 1.29$

$(3 ; 6)$

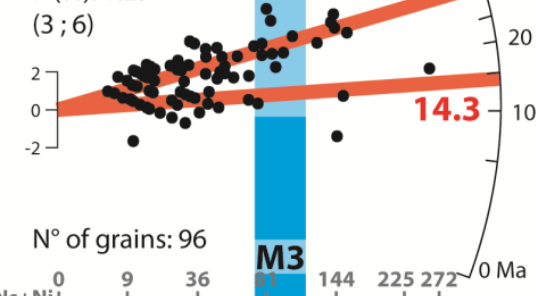
$\mathrm{Ns}+\mathrm{Ni}$

Central Age: $27.4 \pm 2.6$

Chi-sq.: 249.14

$P(\%): 0.0$

$$
(3 ; 6)
$$

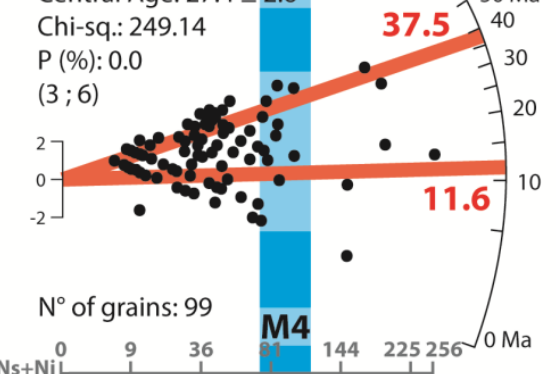

$\mathrm{Ns}+\mathrm{Ni}$

Central Age: $30.1 \pm 2.5$

Chi-sq.: 213.81

$P(\%): 0.0$

$(3 ; 6)$

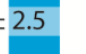

$48.8,50 \mathrm{Ma}$

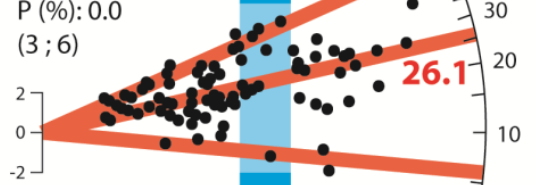

$\mathrm{N}^{\circ}$ of grains: 99

Ns+NiL 2
Southern Tributaries

Central Age: $19.2 \pm 2.4 \quad 47.6 \quad 50 \mathrm{Ma}$

Chi-sq.: 114.16

$\mathrm{P}(\%): 0.0$

$(7 ; 13)$

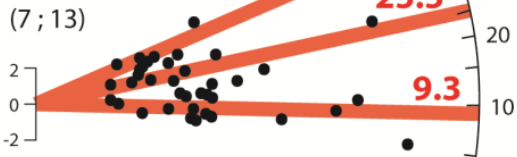

$\mathrm{N}^{\circ}$ of grains: 39

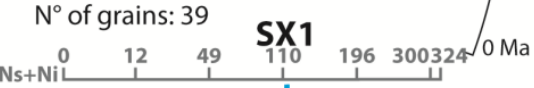

Central Age: $26 \pm 4.2$

Chi-sq.: 403.64

$\mathrm{P}(\%): 0.0$

$(7 ; 13)$

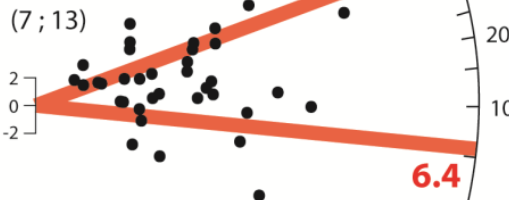

$N^{\circ}$ of grains: 39

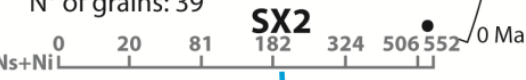

Central Age: $34.4 \pm 7.1$

$\begin{array}{ll}\text { Chi-sq.: } 271.74 & 110.4\end{array}$

$\mathrm{P}(\%): 0.0$

$(9 ; 15)$

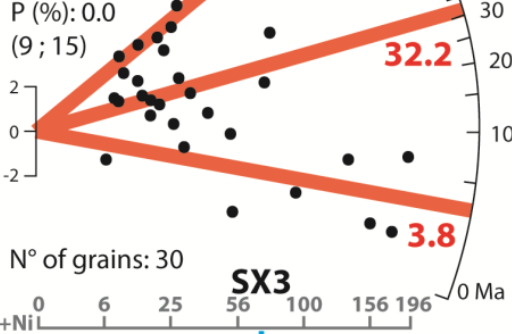

$\mathrm{Ns}+\mathrm{Ni}$

Central Age: $2 \pm 0.5$
Chi-sq.: 79.78
P $(\%): 0.0$
$(9 ; 14)$

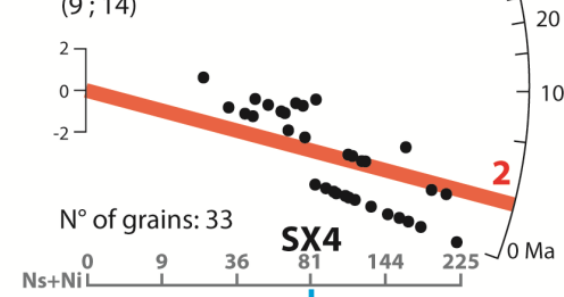

Central Age: $6.9 \pm 1.6$

Chi-sq.: 436.21

$\mathrm{P}(\%): 0.0$

$(12 ; 17)$
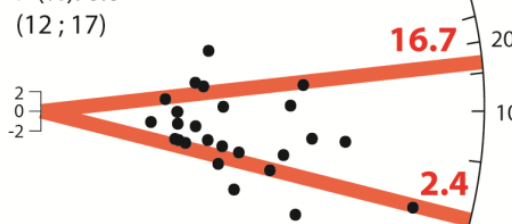

$N^{\circ}$ of grains: 26

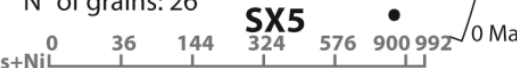

This article is protected by copyright. All rights reserved. 

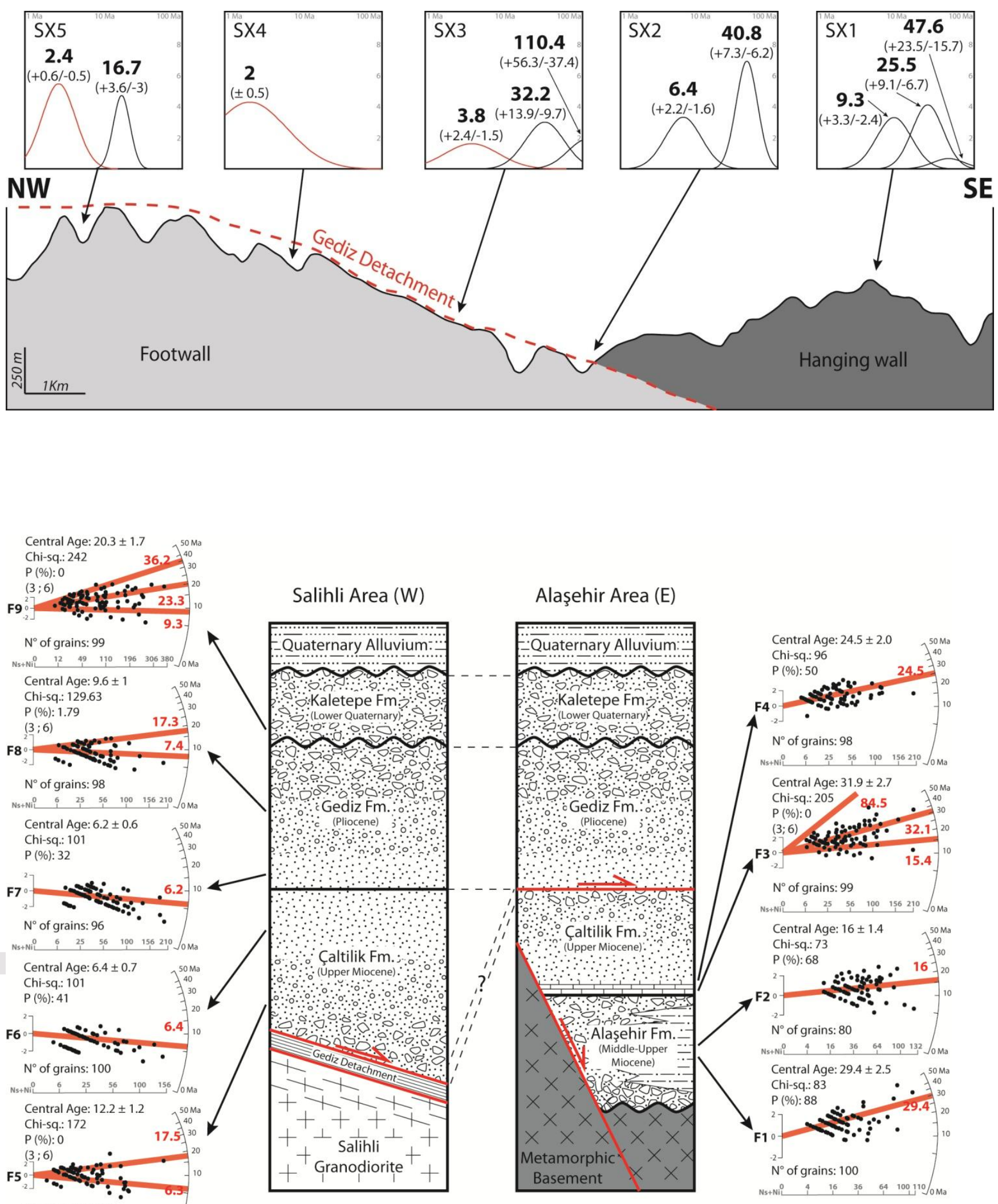

This article is protected by copyright. All rights reserved. 


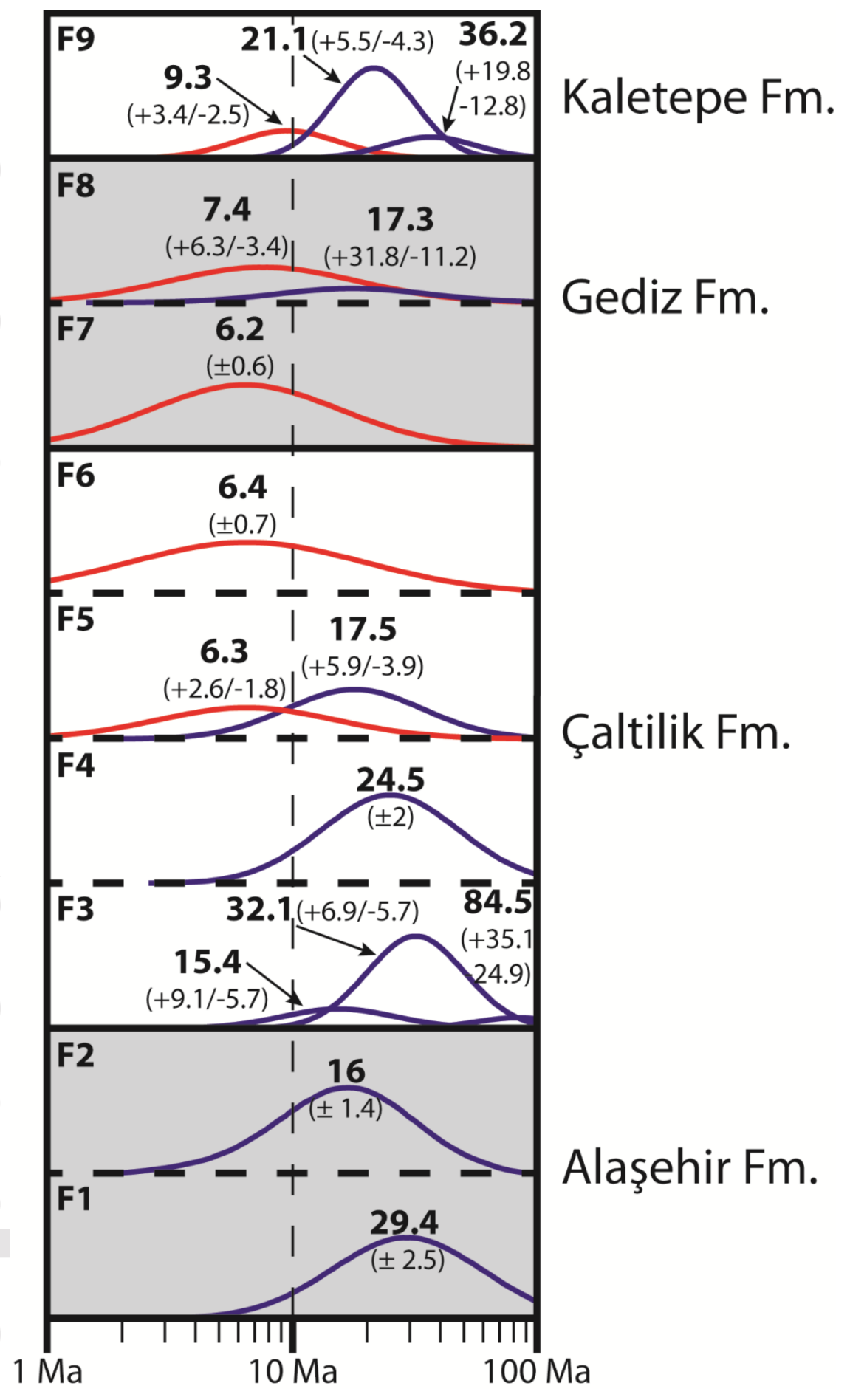



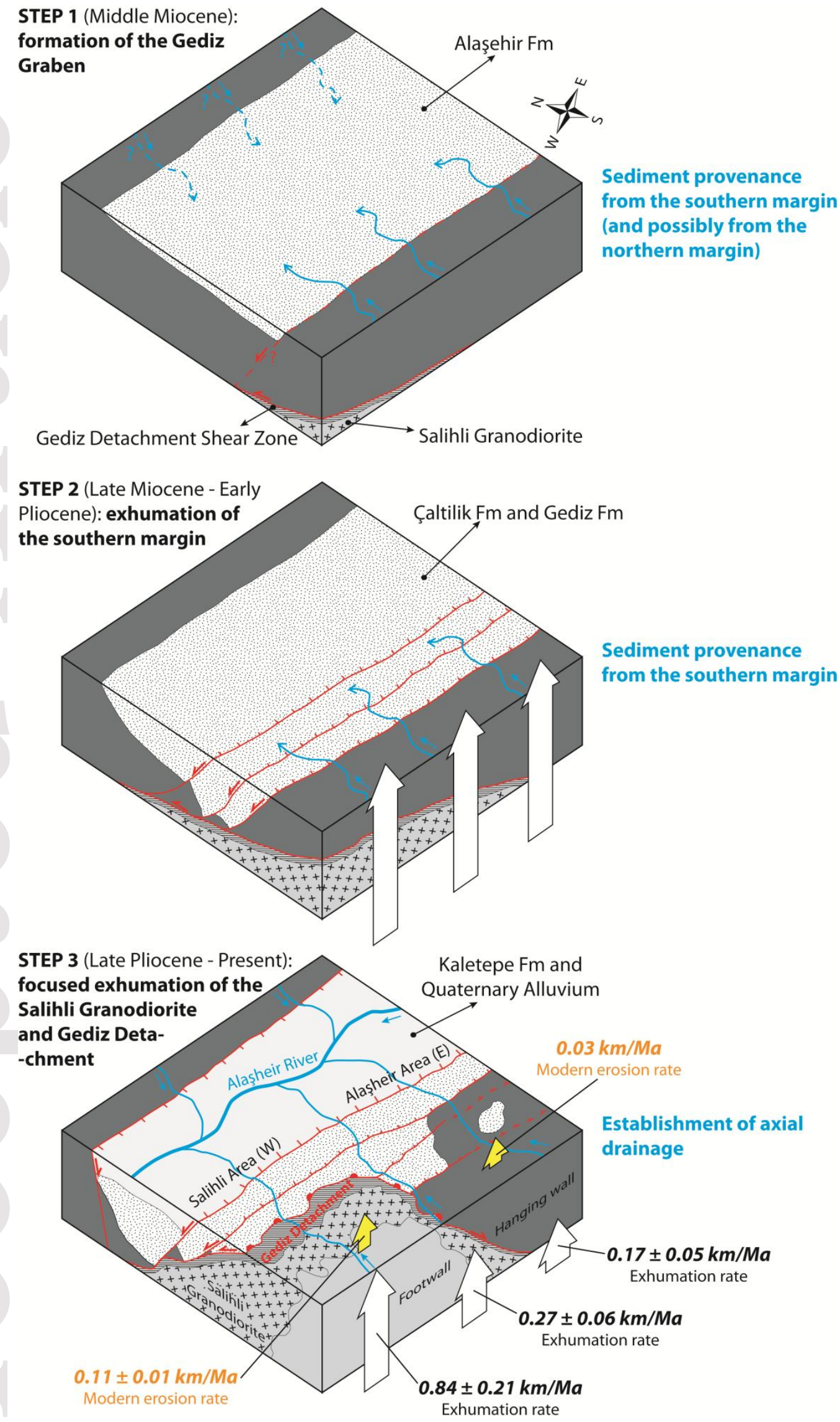

This article is protected by copyright. All rights reserved. 